PONTIFÍCIA UNIVERSIDADE CATÓLICA DO RIO DE JANEIRO

Empreendedorismo e Cultura Organizacional Moderna Estudo de Caso da Reserva

\title{
Eric Gewerc
}

TRABALHO DE CONCLUSÃO DE CURSO

Centro de CIÊnCIAS SOCIAIS - CCS

DePARTAMENTO de AdMINISTRAÇÃo

Graduação em Administração de Empresas

Rio de Janeiro, Junho de 2020. 


\section{Eric Gewerc}

\section{Empreendedorismo e Cultura Organizacional Moderna Estudo de Caso da Reserva}

Trabalho de Conclusão de Curso

Trabalho de Conclusão de Curso, apresentado ao programa de graduação em Administração da PUCRIO como requisito parcial para a obtenção do título de graduação em Administração.

Orientadora: Lygia Alessandra Magalhães Magacho 


\section{Agradecimentos}

Gostaria de agradecer primeiramente aos meus pais, Marcel e Carina Gewerc, por me possibilitarem estudar na PUC, minha gratidão eterna. Gostaria de agradecer também a Bruna Banchik, minha namorada, por dividir comigo diversos momentos tão importantes nesse processo.

À minha orientadora, Lygia Alessandra Magalhães Magacho, por me ajudar nessa etapa tão importante, sem as orientações e conselhos dela, esse processo teria sido muito mais difícil. 


\section{Resumo}

Gewerc, Eric. Empreendedorismo e Cultura Organizacional Moderna - Caso Reserva. Rio de Janeiro, 2020. 54p. Trabalho de Conclusão de Curso Departamento de Administração. Pontifícia Universidade Católica do Rio de Janeiro.

Diante de um mercado tão competitivo que se vive nos dias de hoje, as organizações buscam por diferenciais para sobreviver e prosperar. Uma cultura organizacional orientada ao empreendedorismo pode ser o diferencial para se obter vantagem competitiva. Diversos estudiosos reconhecem a importância que o intraempreendedorismo tem nas organizações. Sendo assim, este trabalho tem como objetivo explorar a existência de uma cultura organizacional orientada ao empreendedorismo no Grupo Reserva, empresa que já ganhou prêmios de revistas conceituadas por ser reconhecida como inovadora em seu mercado de atuação.

Palavras-chave:

Empreendedorismo, intraempreendedorismo, Cultura Organizacional, Inovação,

\section{Abstract}

Gewerc, Eric. Entrepreneurship and Modern Organizational Culture - Reserva Case. Rio de Janeiro, 2020. 54p. Trabalho de Conclusão de Curso Departamento de Administração. Pontifícia Universidade Católica do Rio de Janeiro.

Faced with such a competitive market that we live in today, organizations are looking for differentials to survive and prosper. An organizational culture oriented to entrepreneurship can be the differential to obtain competitive advantage. Several scholars recognize the importance that intrapreneurship has in organizations. Therefore, this work aims to identify the existence of an organizational culture oriented to entrepreneurship at Reserva, a company that has already won awards from renowned magazines for being recognized as an innovator in its market.

Keywords:

Entrepreneurship, intrapreneurship, Organizational culture, Innovation 


\section{Lista de Figuras}

Figura 1: Mural da loja Anália Franco, São Paulo........................................27

Figura 2: E-mail de comunicação interna do departamento de felicidade...........28

Figura 3: Área Social da Reserva................................................................

Figura 4: Produto da linha resistente a água....................................................34

Figura 5: Ferramenta para criação de produtos.............................................35

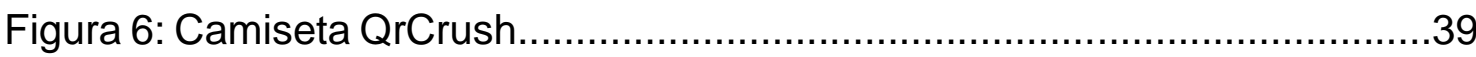

Figura 7: Campanha publicitária da Reserva a partir de um assalto...................42

Figura 8: Produto da coleção colaborativa entre Reserva e New Balance..........45

Figura 9: Chinelo com a marca “Keep Walking”...........................................48 


\section{Sumário}

1. Introdução $\quad 7$

1.1. Objetivo final do estudo 8

1.2. Delimitação do estudo 8

1.3. Relevância do estudo 8

2. Referencial teórico 10

2.1. Empreendedorismo 10

2.2. Cultura organizacional 11

2.3. Cultura Organizacional e Orientação Empreendedora 13

$\begin{array}{ll}\text { 2.3.1. Autonomia } & 14\end{array}$

$\begin{array}{ll}\text { 2.3.2. Inovação } & 14\end{array}$

2.3.3. Capacidade de assumir riscos 15

2.3.4. Proatividade 16

$\begin{array}{ll}\text { 2.3.5. Competitividade Agressiva } & 17\end{array}$

2.3.6. Formação de Parcerias 18

2.3.7. Orientação para o mercado 19

2.6. Gerenciamento Cultural 19

3. Metodologia de pesquisa 22

3.1. Tipo de pesquisa 22

3.2. Coleta de dados 22

3.3. Seleção de sujeitos 23

3.4. Tratamento de dados 23

3.5. Limitações do Estudo 24

4. Análise dos dados 25

4.1. O grupo Reserva 25

4.2. A cultura Reserva e o Departamento de Felicidade 26

4.3. Autonomia 31

4.4. Inovação 33

4.5. Capacidade de Assumir Riscos 36

4.6. Proatividade 38

4.7. Competitividade Agressiva 40

4.8. Formação de Parceria 43

4.9. Orientação para o Mercado 45

5. Conclusão 49

5.1 Sugestões e recomendações para novos estudos 51

6. Referências Bibliográficas 5 


\section{Introdução}

O ambiente de negócios está cada vez mais competitivo e dinâmico, oferecer produtos de qualidade, possuir baixo custo de produção, ser ético em relação às leis e baixo preço de venda não garantem a sobrevivência do negócio a longo prazo. As organizações precisam estar preparadas para passar por adversidades, momentos de turbulência do mercado, mudanças mercadológicas e sociais para conseguir garantir a sustentabilidade da companhia, uma vez que essas dificuldades vêm sempre desafiando as empresas, sejam elas grandes, pequenas ou médias.

Diante deste cenário, se torna extremamente importante para as organizações encontrarem diferenciais para se obter vantagens competitivas. $O$ empreendedorismo dentro da organização (intraempreendedorismo) pode ser mais que um diferencial, mas uma necessidade, para assim, garantir a sua competitividade e sobrevivência.

Em artigo para a revista Harvard Business Review, o professor da escola de negócios de Harvard, Vijay Govindarajan (2013) sinaliza que o banco de inovação corporativa de qualquer organização são seus intraempreendedores. Govindarajan afirma: "o intraempreendedorismo fomenta o aperfeiçoamento, a criatividade e a renovação das empresas, aspectos imprescindíveis à sua sobrevivência no contexto de um mercado sujeito a transformações constantes"

Uma vez que o empreendedorismo é de suma relevância para as empresas, é importante que esteja presente no cotidiano da organização, nos hábitos dos colaboradores, no mindset das lideranças, e dessa forma, na cultura organizacional. Compreendendo a importância e a relevância do tema cultura organizacional e empreendedorismo, este estudo de caso busca identificar se existe uma cultura organizacional orientada ao empreendedorismo na empresa Reserva.

Existem diversos fatores que chamam a atenção na companhia, como por exemplo, o fato de ter sido a única empresa brasileira nomeada pela revista americana Fast Company (2015) como uma das empresas mais inovadoras do mundo, ao lado de empresas como Google, Tesla e Samsung. Além disso, a 
empresa aparece recorrentemente no ranking do Great Place to Work, que lista as melhores empresas do Brasil para se trabalhar.

Outro fator curioso a respeito da organização, é a existência de um departamento intitulado "Felicidade". O departamento de felicidade é responsável pela tangibilização e propagação do que é chamada a "Cultura Reserva" para os colaboradores, a partir de três pilares: Inovação, Família e realização de sonhos.

Com isso, surgiu o interesse de se entender como a cultura organizacional influência neste ambiente, que é considerado inovador por instituições renomadas.

\subsection{Objetivo final do estudo}

Este estudo tem como propósito principal a análise da cultura organizacional da empresa Reserva e seus principais aspectos, para assim, conseguir determinar se existe uma cultura organizacional orientada ao empreendedorismo na empresa.

\subsection{Delimitação do estudo}

O estudo pretende identificar a existência de uma cultura organizacional orientada ao empreendedorismo na Reserva, e sabe-se, que a cultura tem como um dos objetivos a alavancagem dos resultados financeiros da organização, mas está fora do escopo do trabalho realizar análises de impactos financeiros da companhia.

\subsection{Relevância do estudo}

Este estudo é importante pois aborda a questão da gestão de cultura organizacional e empreendedorismo de forma prática em uma empresa de grande porte, segundo a classificação do Sebrae (2013), que possui mais de 
1.500 funcionários.

O conhecimento apresentado neste trabalho poderá auxiliar a empresa Reserva, objeto do estudo, e empresas que entendem a relevância da cultura organizacional, que podem se utilizar do benchmark de empresa que tem um modelo definido de gestão cultural.

Além da relevância prática, o estudo pode também ser utilizado no meio acadêmico em geral na área Administração de Empresas na temática de cultura organizacional e empreendedorismo. 


\section{Referencial teórico}

\subsection{Empreendedorismo}

Segundo Shapero (2004), em praticamente qualquer definição de empreendedor existe um consenso, um padrão comportamental usual: tomar decisão, organizar e reorganizar mecanismos sociais e econômicos a fim de transformar recursos e situações em um benefício prático.

Schumpeter (1982) associa empreendedorismo ao desenvolvimento econômico e apresenta como ações inovadoras tem o poder de criar descontinuidades cíclicas na economia e associa o empreendedor a um indivíduo que abala a ordem econômica estabelecida. Segundo o mesmo autor, existem três pilares centrais que os empreendedores se fixam: assumir riscos, inovação e exposição da economia ao estado de desequilíbrio, onde o empreendedor se desprende de paradigmas que anteriormente se encontravam definidos.

O autor afirma ainda que, o empreendedor é responsável pela realização de novas combinações, que podem ser observadas pela introdução de um novo bem ou serviço, introdução de um novo método de comercialização ou produção, abertura de novos mercados, ou qualquer atividade que tenha como objetivo o estabelecimento de uma nova organização de alguma indústria, novos negócios ou novas maneiras de se realizar atividades.

Drucker (1992) afirma que o empreendedor é aquele que pratica a inovação sistemicamente, buscando e criando oportunidades. Para o autor, existem sete fontes para existir uma oportunidade de inovação: o inesperado, mudanças estruturais, mudanças de percepções, novos conhecimentos científicos, mudanças demográficas, uma necessidade e contradições entre 0 que é e o que deveria ser.

Segundo Dolabela (1999), o conceito de empreendedorismo possui uma denotação prática e envolve atitudes e ideias. Significa realizar coisas novas ou criar formas novas de se realizar as coisas. $O$ autor afirma que o termo possui uma grande abrangência, que não trata apenas da abertura de empresas, mas 
também de geração de autoemprego (trabalhadores autônomos), empreendedorismo comunitário, intraempreendedorismo (empregado que empreende na empresa) e políticas públicas.

De acordo com Hisrich e Peters (2004), o intraempreendedorismo é um elo extremamente importante de ligação entre a ciência e o mercado. $O$ autor afirma que as burocracias e as estruturas altamente hierarquizadas inibem a criatividade, dificultando a criação de novos produtos e negócios dentro das organizações. O conhecimento das necessidades de criatividade e inovação auxiliam para que exista um espírito intraempreendedor em suas organizações.

Portanto, compreende-se que o empreendedorismo é um fator essencial para a transformação de estruturas econômicas e quebra de paradigmas, além de um grande alicerce para a transformação diária das empresas já estabelecidas.

\subsection{Cultura organizacional}

O segundo conceito a ser abordado é o conceito de cultura organizacional, analisando e detalhando seus diversos aspectos, suas funções, divisões e seus elementos.

A Cultura é utilizada pela sociologia, para assim, se ter uma melhor compreensão de grupos urbanos e relacionamentos, aumentando assim seu conhecimento da sociedade, a partir de grupos sociais.

Segundo Robbins (2005), o termo cultura organizacional passou a ter bastante relevância para a Administração nos anos 1980, quando administradores americanos passaram a estudar como se criar vantagem competitiva através da cultura organizacional.

Tylor apud Horton e Hunt (1980, p.40) afirma que cultura "é aquele todo complexo que inclui conhecimento, crença, arte, moral, direito, costumes e outras capacidades e hábitos adquiridos pelo homem como membro da sociedade".

Schein (1992, p.12), define Cultura como: 


\begin{abstract}
"Um padrão de premissas básicas compartilhadas que o grupo aprendeu à medida que resolvia seus problemas de adaptação externa e integração interna, que funcionou suficientemente bem para ser considerada válida e, portanto, para ser ensinada aos novos membros como o meio correto de perceber, pensar e sentir em relação àqueles problemas".
\end{abstract}

Para Mintzberg (2000), a cultura é composta de interpretações de um mundo e das atividades e artefatos que refletem as mesmas. Essas interpretações são compartilhadas coletivamente em processos sociais. Ainda segundo Mintzberg, não existem culturas particulares, pois sua essência é coletiva.

A cultura de uma empresa possui dois tipos de elementos: visíveis e invisíveis. Elementos visíveis são aqueles que conseguimos enxergar visualmente como o layout das comunicações internas, a forma de se vestir, a construção da empresa, entre outros. Já os elementos invisíveis são mais difíceis de serem identificados, pois não podem ser identificados de forma explícita, tais como as crenças, as atitudes e os sentimentos. Stoner e Freeman (1995) afirmam que a cultura pode ser comparada a um iceberg, onde, na superfície estão os aspectos visíveis e formais, como objetivos, tecnologia, estrutura, entre outros, enquanto abaixo dela estão os aspectos ocultos e não formais como percepções, atitudes, valores, sentimentos, entre outros.

Schein (2009) define que a cultura organizacional possui três funções básicas: fornecer um sentimento de continuidade aos membros da organização; propiciar condições de adaptabilidade e flexibilidade organizacional frente às mudanças externas; proteger a empresa de possíveis ameaças externas fruto das duas funções ilustradas anteriormente.

Mintzberg (2000) diz que a cultura organizacional é o caminho mais eficaz e sustentável para desenvolver barreiras à imitação, porque a cultura fortalece a produção de resultados únicos, sendo difícil compreender em sua plenitude, o que dificulta ainda mais a sua cópia. Da mesma forma que pode ser uma força, a cultura organizacional pode ser uma fonte de dificuldades e são citados três fatores que podem implicar em barreiras de uma cultura organizacional: barreiras às mudanças; barreiras a diversidade; barreiras a aquisições e fusões. 


\subsection{Cultura Organizacional e Orientação Empreendedora}

Segundo Salles (2011), existe uma grande relação entre orientação empreendedora e a cultura organizacional. Ainda segundo Salles (2011), orientação empreendedora é um conjunto de processos, práticas e atividades de tomada de decisão que asseguram a sobrevivência ou a continuidade da empresa e tem como objetivo levar um negócio existente a novos empreendimentos. Novos empreendimentos em uma organização têm como objetivo fim a sobrevivência da organização em um ambiente repleto de ameaças internas e externas.

Dolabela (2008) constatou em suas pesquisas que o empreendedorismo é um fenômeno cultural, ou seja, é consequência de hábitos, práticas e valores de um grupo. Dessa forma, existem empresas mais empreendedoras que outras, assim como países, cidades e regiões. $\mathrm{O}$ autor explica que se aprende a ser empreendedor da convivência com outros empreendedores, e por isso, a cultura de uma empresa pode, de fato, influenciar para que a organização tenha um perfil empreendedor.

O dinamismo tem como consequência a rápida tomada de decisões com foco em atingir as metas e objetivos estratégicos, assegurando, dessa forma os resultados futuros e a saúde financeira da organização.

Para Oliveira Júnior (2009) em empresas com orientação empreendedora a vontade de inovar predomina, levando o empreendedor a assumir riscos, desenvolver uma agressividade frente às empresas concorrentes em seus segmentos e ser proativo em relação às oportunidades de mercado.

Salles (2011) afirma que existem sete dimensões que indicam a orientação empreendedora: autonomia, inovação, capacidade de assumir riscos, proatividade, orientação para o mercado, formação de parcerias e competitividade agressiva. 


\subsubsection{Autonomia}

Segundo Salles (2011), a autonomia está relacionada à busca de uma idealização e sonhos, no qual empreendedores tem como objetivo pôr em prática a liberdade de suas ideias, pensamentos e ações que são suplantadas dentro do ambiente da empresa. Salles (2011) afirma que mesmo reconhecendo a importância do empreendedorismo, muitas organizações não concedem muita autonomia a seus colaboradores, mas ao mesmo tempo cobram criatividade e soluções para seus problemas.

Oliveira Júnior (2009) afirma que a autonomia se refere a independência para ação dos indivíduos ou grupos em trazer uma ideia ou visão e a implementarem por completo. Para o processo de autonomia ser bem-sucedido, precisa ser aceito e integrado a empresa em seu conceito de estratégia organizacional. Ainda segundo o autor, a alta administração de uma organização deve não só permitir, mas incentivar a atuação de grupos autônomos em todos os níveis organizacionais, implementando mudanças necessárias na estrutura organizacional e assim, estimular novas ideias e reforçar o pensamento criativo que os colaboradores tomem decisões. Oliveira Junior (2009) ressalta ainda a importância do reconhecimento dos colaboradores nesse processo.

Miller (1983) constatou em seus estudos que quanto mais empreendedora é uma organização, mais autônomos são as lideranças da empresa.

\subsubsection{Inovação}

Salles (2011) afirma que em tempos atuais, com mercados extremamente competitivos, para alcançar o sucesso, novas capacidades são essenciais. Trata-se de uma era onde a alocação de tecnologias, ativos físicos e a excelência em gestão não são fatores suficientes para garantir as vantagens competitivas e a sobrevivência de uma organização. Nesse contexto, entra a importância do capital intelectual, que é o gerador da inovação.

Oliveira Junior (2009) afirma que a inovação é vista por diversos 
estudiosos como fator essencial para uma empresa competir eficazmente tanto em mercados nacionais, quanto internacionais. $O$ autor afirma ainda que para alguns estudiosos, a inovação é a principal ou uma das mais importantes características de uma atividade empreendedora. A inovação pode gerar recursos raros e valiosos para a empresa, assim gerando vantagem competitiva para a organização.

Segundo Oliveira Junior (2009), a inovação reflete a tendência de uma organização em se envolver e incentivar novas ideias, experimentos, singularidades, mas principalmente, em apoiar processos criativos que resultem em produtos pioneiros, serviços ou processos tecnológicos que gerem uma vantagem competitiva. A inovação, segundo o autor, pode ser de dois tipos: inovação do produto ou inovação tecnológica, sendo que em ambos os casos, apesar do diferente enfoque, é necessário que se invista em pesquisa e desenvolvimento.

Oliveira Junior apud Miller (1992) afirma que empresas empreendedoras veem a inovação como o estado natural das coisas, uma vez que estão sempre olhando para as oportunidades de estar à frente em seus mercados.

A inovação traz um elevado nível de incerteza, tanto para o bem, quanto para o mal, e por isso, é importante o desenvolvimento de práticas que tenham como objetivo reduzir o risco associado ao negócio.

\subsubsection{Capacidade de assumir riscos}

Segundo Oliveira Junior (2009), os empreendedores, sejam eles os que criam novas empresas, ou os colaboradores que empreendem dentro da empresa que trabalham (intraempreendedores) tomam mais riscos relacionados ao negócio do que a média dos empregados ou a população como um todo. Ambos os perfis de empreendedores tentam minimizar o risco assumido, onde para o empreendedor empresário o maior risco é o risco financeiro do investimento em sua empresa, enquanto para o intraempreendedor o maior risco envolve a sua reputação e projeção de carreira.

Segundo Salles (2011), ao analisar o risco, entende-se que ele possui 
variados significados onde, o contexto, o mercado que a empresa está inserida e também o apetite por explorar o desconhecido são alguns deles. Junto ao risco existe a incerteza, o risco pessoal, social e psicológico. Por isso, o empreendedor deve ser destemido, pois ao explorar um novo território, com pouco ou nenhum conhecimento prévio, pode-se obter consequências catastróficas.

Salles (2011) afirma que organizações propensas a tomar riscos tomam decisões para a criação de novos produtos, serviços, de investir no negócio ou ainda de criar novas empresas mesmo com o possível risco de uma grande perda financeira para a companhia. Afirma ainda que, a liderança é essencial no processo de tomada de riscos, uma vez que as lideranças têm a capacidade de influenciar a organização como um todo. O autor ressalta ainda que empresas empreendedoras apoiam seus colaboradores que por ventura falham em momentos que assumem riscos e não obtém o êxito esperado em suas empreitadas.

Oliveira Junior (2009) afirma que conforme a empresa vai crescendo e atingindo um estágio mais avançado, a tendência é que a capacidade de assumir riscos vá diminuindo, por ter que ser aprovada em várias etapas antes de ser colocada em prática. $\mathrm{O}$ autor afirma ainda que, grandes empresas tendem a buscar projetos que estimam altos retornos com baixo risco, mas que são extremamente difíceis de serem encontrados.

\subsubsection{Proatividade}

O comportamento proativo é aquele que antecipa mudanças e altera 0 ambiente, é usualmente visto como uma forma de sobrevivência das empresas e de efetivamente ter vantagens competitivas com as mudanças, afirma Oliveira Junior (2009) apud Sandberg (2002). Para o autor, a vantagem de ser o primeiro a entrar no mercado é a melhor estratégia para capturar novas oportunidades. Dessa forma, a proatividade, através da busca de novas oportunidades e participação em mercados emergentes tornou-se associada ao empreendedorismo. 
Segundo Salles (2011) o comportamento proativo necessariamente está relacionado a ação, antecipando movimentos que podem resultar em mudanças de um ambiente. Muitas empresas viraram líderes em seus ramos de atuação por anteciparem seus produtos ou serviços, criando, uma dependência entre o mercado e os produtos, estabelecendo assim a sua marca. $\mathrm{O}$ autor enfatiza ainda que as organizações que são pioneiras no lançamento de novos produtos e serviços alcançam resultados mais elevados.

Uma estratégia baseada em proatividade é aquela em que a empresa atua antes de ser forçada a reagir às mudanças e oportunidades do ambiente, relata Oliveira Junior (2009). Por outro lado, o autor cita que em alguns casos a proatividade pode ser reativa, não ao ambiente, mas sim a sintomas de uma mudança que pode estar por vir. Empresas proativas precisam ter facilidade e agilidade para se adaptar a essas iminentes mudanças.

Ainda segundo Oliveira Junior (2009), empresas que criam inovações radicais são frequentemente citadas como exemplos de proativas, uma vez que possuem a capacidade de ligar as inovações radicais e tem o poder de criar 0 seu próprio mercado.

\subsubsection{Competitividade Agressiva}

A competitividade agressiva existe dentro de pequenas, médias e grandes empresas, e pode ser considerada um ato de sobrevivência ou posicionamento estratégico frente aos competidores para buscar a liderança do mercado. (Salles,2011). Como a competitividade agressiva pode gerar perdas para as empresas, diversos gestores estratégicos não têm facilidade em decidir se devem procurar ou evitar confrontos competitivos.

Lupkin e Dess (1996) apud Salles (2011) relatam que a competitividade agressiva está relacionada ao quanto uma organização está disposta a desafiar intensivamente os seus competidores ao entrar em um determinado mercado ou melhorar sua posição, para assim, superar os concorrentes. Os autores afirmam ainda que, empresas que possuem o comportamento competitivo agressivo refletem o desejo de fugir do convencional, e dessa forma, quebrar vínculos com 
os métodos tradicionais de competição.

Oliveira Junior (2009) afirma que a velocidade com que as ações são implementadas, são consideradas dos mais fortes e consistentes aspectos para que haja o perfil de competitividade agressiva em uma organização. $O$ autor afirma ainda que, empresas com o perfil competitivo agressivo geralmente possuem posturas menos previsíveis do que empresas com a postura mais passiva.

Empresas competitivas agressivas geralmente apresentam melhor desempenho em ambientes hostis, relata Oliveira Junior (2009). Além disso, apresentam altas médias em investimentos em marketing inovador, propaganda, qualidade do produto, operações inovadoras e feedbacks de clientes, gerando grandes vantagens para as organizações em um ambiente competitivo.

\subsubsection{Formação de Parcerias}

As parcerias estratégicas têm se tornado cada vez mais importante para as empresas, uma vez que podem dar acesso à informação, recursos tangíveis e intangíveis e tecnologias em um ambiente empresarial competitivo, relata Oliveira Junior (2009). A formação de parcerias permeia clientes, fornecedores e outras empresas, onde o maior benefício para as organizações está na capacidade necessária para se competir de forma eficaz no mercado.

Oliveira Junior (2009) defende ainda que, as organizações empreendedoras estão se utilizando da estratégia de formação de parcerias para atingir seus objetivos estratégicos. A formação de parcerias está relacionada ao fortalecimento de relações de longo prazo entre a organização e terceiros que possuem posição chave no mercado onde está inserido ou que se deseja inserir. As parcerias estratégicas podem ainda, ser um grande aliado para a inovação dentro de uma organização, uma vez que combina dois ou mais parceiros que têm diferentes expertises com objetivo de criar algo novo para o mercado.

Para Salles (2011) a formação de parcerias é benéfica para empresas pois abre um canal indireto de fontes de conhecimentos disponíveis, uma vez que existe um comportamento de cooperação entre as partes envolvidas. Por 
outro lado, quando uma das empresas vê a relação com um olhar egoísta e oportunista e não atua como parceiro de fato, a parceria pode vir a falhar e ir a extinção, atrapalhando no atingimento de objetivos por parte de um dos lados.

\subsubsection{Orientação para o mercado}

Empresas orientadas ao mercado tem como objetivo o aumento da fidelização da sua base de clientes, sendo uma resposta direta ao seu desempenho. Essas empresas focam em atender as necessidades e desejos de seus clientes de forma mais eficiente que seus concorrentes de mercado, relata Salles (2011). O mesmo autor afirma que existem quatro competências principais associadas a orientação para o mercado, são elas: orientação ao cliente, satisfação do cliente, marketing e foco no lucro.

Oliveira Junior (2009) afirma que existe uma grande relação entre a orientação ao mercado com o empreendedorismo, uma vez que empresas voltadas para o mercado são empreendedoras, pois buscam estar sempre criando novos produtos para atender ao seu mercado.

Oliveira Junior (2009) afirma que organizações suficientemente orientadas ao mercado tem riscos de falha reduzidos, pois as necessidades, atuais e futuras de seus clientes são o foco dos esforços da empresa. Por isso, é necessário que a empresa esteja também atenta ao que os concorrentes de mercado estão fazendo. O autor cita ainda uma pesquisa feita com 246 empresas de diversos segmentos, que para se ter uma alta performance e crescimento organizacional, a orientação ao mercado é um pré-requisito. Nessa pesquisa, todas as empresas que apresentaram mais alta performance, foram aquelas que de fato combinaram a orientação com o mercado com a orientação empreendedora.

\subsection{Gerenciamento Cultural}

A questão de gerenciamento de cultura é polêmica no meio acadêmico, pois existem duas diferentes visões que se contrastam nesse ponto. Alguns 
autores defendem que é possível gerenciar a cultura em uma organização, enquanto outros autores defendem que não é possível.

Tomei (2002) afirma que a cultura de uma organização leva tempo para se formar e desenvolver, portanto se cria e se mantém uma ordem, e por isso, mudá-la é um processo lento difícil e nem sempre bem-sucedido. A mesma autora defende que é bem mais fácil ajustar as manifestações de cultura do que modificar o núcleo de crenças e pressupostos básicos em uma organização.

Ainda segundo Tomei (2002), a literatura organizacional identifica quatro situações potenciais favoráveis para mudanças e gerência de cultura na organização:

1ํ: Fusões, aquisições, reestruturações, terceirizações e privatizações;

2ํ: Fatores externos como recessão, oportunidades tecnológicas e de mercado;

$3^{\circ}$ : Crises internas e processo de sucessão de poder;

4ํ: Processo de socialização de novos membros da organização;

Schein (2009) argumenta que a maneira como a cultura pode ser mudada depende fundamentalmente do estágio evolucional em que se encontra, e existem três estágios organizacionais:

1. Fundação e crescimento inicial onde mudanças podem ser feitas de forma incremental por meio de evolução geral e específica e promoção de lideranças flexíveis dentro da cultura;

2. Meia-Vida onde mudanças podem ser feitas por promoção sistemática de subculturas selecionadas, infusão de pessoas de fora ou sedução tecnológica; e

3. Maturidade e declínio onde mudanças podem ser feitas através de explosão de mitos, fusões e aquisições ou destruição e renascimento.

Segundo Fleury (1989), quando o gerenciamento da cultura organizacional é de afirmação da cultura vigente, ou seja, da manutenção dos padrões e controle dos elementos, as possibilidades de êxito são maiores. A organização investe em desenvolver as práticas organizacionais, os ritos e 
rituais para assim manter os valores básicos da organização. Por outro lado, quando a proposta é de mudança de padrões, a questão se torna bem mais complexa, pois pode existir grande resistência dos vários segmentos da organização. 


\section{Metodologia de pesquisa}

\subsection{Tipo de pesquisa}

Para a realização deste estudo, foi utilizada pesquisa que pode ser considerada tanto descritiva quanto explicativa. Descritiva porque expõe características e trejeitos da população da determinada empresa em questão, e explicativa pois, a partir da pesquisa descritiva, o trabalho buscou explicar os fatores que contribuem para os resultados obtidos. O questionário formulado tem o intuito de colher informações relevantes sobre como o departamento de felicidade influencia na cultura organizacional da companhia.

Para Selltiz (1965), as pesquisas descritivas têm como objetivo a apresentação de um fenômeno ou situação de forma minuciosa, chamando a atenção para o que está ocorrendo. Segundo ele, essa forma de pesquisa tem a faculdade de possibilitar o entendimento exato da realidade, com as características do indivíduo ou grupo e como eles se relacionam com os fatos experimentados.

O estudo de caso em questão também é considerado participante, pois o responsável pela pesquisa é um colaborador da organização e, está envolvido naturalmente com a organização e a cultura da mesma. Não é considerada uma pesquisa-ação pois não há intervenção do autor com a realidade do ambiente durante a pesquisa ou objetivo de intervenção após a pesquisa.

\subsection{Coleta de dados}

A coleta de dados aconteceu entre os dias 27 de abril e 04 de maio de 2020 através de entrevistas com 12 colaboradores do grupo Reserva. O roteiro das entrevistas foi do tipo semiestruturado, onde as perguntas foram feitas de forma aberta para existir uma maior liberdade aos entrevistados em fornecer informações adicionais.

As entrevistas foram realizadas por Eric Gewerc, autor do trabalho, por 
meio de vídeo conferências. As entrevistas foram gravadas pelo aplicativo Zoom e estão disponíveis para consulta. É importante ressaltar que as entrevistas não foram realizadas de forma presencial devido a pandemia de Covid-19.

Além disso, foram coletados dados secundários a partir de notícias que foram publicados em meios digitais, sites de informações abertas ao público geral, no site da empresa e em seus canais de conteúdo próprio como o blog 2 minutos e redes sociais.

\subsection{Seleção de sujeitos}

A seleção de colaboradores escolhidos para as entrevistas foi constituída por colaboradores de diferentes departamentos, cargos, idade e tempo de empresa, englobando funcionários da sede administrativa, do centro de distribuição e das lojas da empresa.

A tabela 1 abaixo mostra cada entrevistado, seu cargo e tempo de empresa e suas principais características.

Tabela 1: Perfil dos profissionais entrevistados

\begin{tabular}{|l|l|r|l|}
\hline Nome & Cargo/setor & Idade & Tempo de empresa \\
\hline Igor Monteiro & Analista de escola de Rebeldia & 27 & 2 anos \\
\hline Rafaela Lima & Analista comercial & 26 & 5 anos \\
\hline Pedro Lameu & Coordenador de logistica (cd) & 33 & 8 anos \\
\hline Renata Tobias & Coordenadora Felicidade & 39 & 6 meses \\
\hline Claudia Moraes & Diretora de compras & 55 & 9 anos \\
\hline lan Coutinho & Analista de Trade Marketing & 25 & 2 anos \\
\hline Priscila Flores & Compradora & 31 & 5 anos \\
\hline Clara Farias & Estagiaria de gerência de projetos & 22 & 2 anos \\
\hline Diego Portugal & Gerente de loja & 30 & 5 anos \\
\hline Pedro Parreira & Head de Criação Rsv+ & 27 & 5 anos \\
\hline Alan Abreu & Analista de sustentabilidade & 23 & 1 ano \\
\hline Rodrigo Berutti & Gerente de produtos digitais & 35 & 9 anos \\
\hline
\end{tabular}

Fonte: O Autor (2020)

\subsection{Tratamento de dados}

Após a realização das entrevistas, os dados foram transcritos e 
analisados qualitativamente, para assim, o autor descrever e interpretar as respostas dos colaboradores entrevistados. O referencial teórico foi utilizado para um melhor entendimento dos achados na pesquisa de campo.

\subsection{Limitações do Estudo}

Segundo Gil (2007), a pesquisa bibliográfica possui limitações pois a possibilidade dos dados arrecadados estarem equivocados existe. Desse modo, a qualidade da pesquisa pode ser comprometida, pois existe a possibilidade de reprodução de equívocos de autores anteriores.

Uma pesquisa qualitativa pode ser tendenciosa e o modo que é interpretada é relativa às convicções do colaborador que foi entrevistado. Além disso, se o entrevistado não possui motivação para colaborar com o projeto, pode mentir ou enganar o entrevistador. Dessa forma, é importante ter um bom tempo para a coleta dos dados.

Buscou-se minimizar essas limitações por meio da proximidade do pesquisador com os colaboradores que aceitaram voluntariamente participar do estudo em questão, assim como o autor se preocupou em permitir que o entrevistado sinalizasse a disponibilidade de tempo necessário para a realização das entrevistas. 


\section{Análise dos dados}

\subsection{O grupo Reserva}

A empresa objeto do presente estudo, a Reserva, é um grupo de marcas de moda premium criada no Rio de Janeiro. Sua sede administrativa e centros de distribuição são localizados no Rio de Janeiro, no bairro de São Cristóvão. A Reserva foi criada no ano de 2006 por Rony Meisler e Fernando Sigal, que começaram criando uma única bermuda e revendendo para seus amigos e familiares. Um pouco depois, abriram a primeira loja em Ipanema, e desde então a marca cresceu e hoje são mais de 90 lojas do grupo, entre lojas próprias e franquias, espalhadas pelo território do Brasil. Além das lojas, a Reserva também tem um e-commerce, vende seus produtos em marketplaces, e está presente em mais de 1.400 (hum mil e quatrocentos) pontos de vendas de multimarcas espalhadas por todo território nacional, segundo o livro "Rebeldes tem asas", livro que conta a história do grupo Reserva. (PUGLIESE, 2017)

O grupo Reserva atualmente conta com sete diferentes marcas, com diferentes estilos e características:

- Reserva: maior e primeira marca do grupo, que trabalha com um estilo de moda casual premium para o público masculino.

- Reserva Mini: marca de moda infantil, para crianças de 0 a 14 anos.

- Oficina Reserva: marca de moda masculina com foco em alfaiataria, com produtos personalizados sob medida.

- Eva: marca de moda de luxo, voltada para o público feminino.

- AhIma: marca de moda voltada para a sustentabilidade, com produtos masculinos, femininos e unissex.

- Rsv+: célula colaborativa que produz collabs entre a Reserva e marcas que tenham sinergia com o grupo, como por exemplo a New Balance.

- Reserva Ink: marca para artistas venderem suas estampas online 
sem se preocuparem com a operação.

O grupo Reserva conta com uma mão de obra com mais de 1.500 (hum mil e quinhentos) colaboradores espalhados entre lojas, centro de distribuição e sede administrativa.

Neste trabalho os funcionários da Reserva são chamados de colaboradores, pois assim se referiram a si mesmo nas entrevistas.

\subsection{A cultura Reserva e o Departamento de Felicidade}

Em "Rebeldes tem Asas", livro que conta a história do grupo desde o seu lançamento, Rony Meisler, sócio fundador, e atual CEO do grupo afirma "É da nossa cultura, e não da nossa estratégia, que nasceu, e sempre nascerá, a nossa prosperidade". (PUGLIESE, 2017)

A Reserva sempre se colocou para o mercado como uma marca que não procura transações comerciais, mas sim relacionamentos sinceros e duradouros, e dessa forma se coloca não como uma empresa que vende roupas para pessoas, mas sim uma empresa de pessoas que vendem roupas, saindo assim do lugar comum das empresas do varejo de moda.

As pessoas da Reserva não gostam que suas lojas sejam chamadas de ponto de vendas, mas sim pontos de encontro, onde os clientes são amigos da empresa, que vão para tomar uma cerveja, jogar um videogame, conversar com um vendedor, e a venda é uma consequência natural dessa relação, em um ambiente totalmente diferente de uma simples loja.

As pessoas são, de fato, o que a Reserva mais valoriza e se preocupa, onde seu propósito está descrito em paredes na sede administrativa e em lojas sendo "Cuidar, emocionar e surpreender as pessoas todos os dias". 
Figura 1: Mural da loja Anália Franco, São Paulo

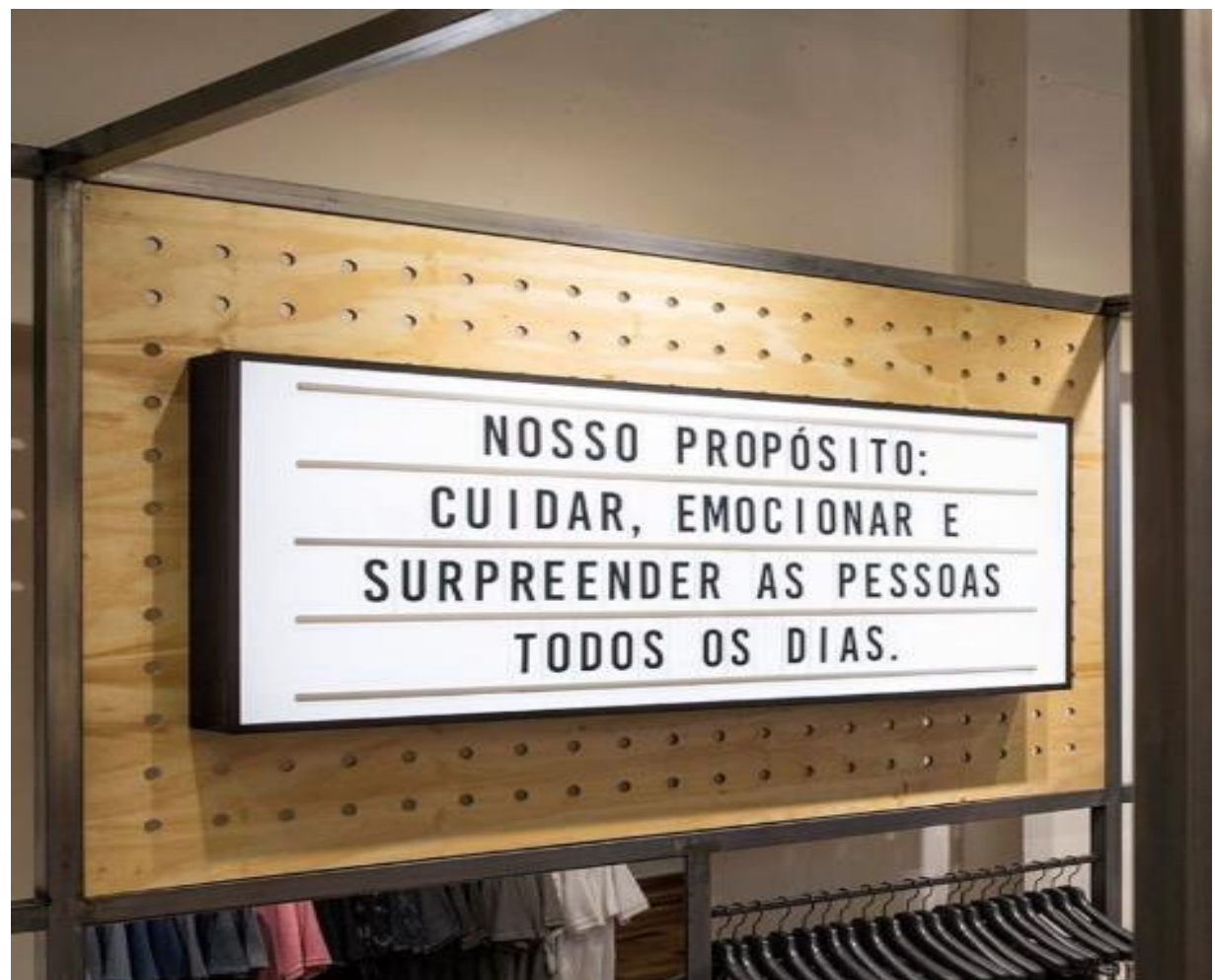

Fonte: Facebook da Reserva (2019)

Em relação a isso, a entrevistada Clara Farias, estagiária de produtos digitais, falou:

\begin{abstract}
"Eu acho que o propósito da Reserva, mencionei isso algumas vezes, é ser mais amigo do que ser uma marca que vende roupa: cuidar, emocionar e surpreender as pessoas todos os dias. Então eu acho que esse propósito está muito alinhado comigo, e acho que com muitas pessoas da empresa, porque a gente tem amigos, a gente tem família, namorados, maridos, mulheres, enfim, então eu acho que um pouquinho do que a gente faz para as pessoas que a gente ama, que é surpreendê-las, deixá-las felizes, agradar, é o que a Reserva quer fazer com seus funcionários, então eu acho que esse propósito está muito ligado nesse sentido, que a gente vê que ela tá querendo entregar para o usuário dela o mesmo que a gente quer entregar para as pessoas que a gente gosta."
\end{abstract}

A Reserva, desde sua criação, tem em sua essência a ideia de fugir do óbvio, não querer apenas o que já está no mercado, e isso está explícito em seus valores, expostos no livro Rebeldes tem Asas, “ Não curtimos a zona de conforto e usamos a adversidade a nosso favor. Não temos medo de arriscar nem de fracassar". (PUGLIESE, 2017)

Nesse contexto, foi criado um departamento dentro da Reserva que, segundo o entrevistado Igor Monteiro, analista da escola de Rebeldia, e antigo 
analista do departamento, tem como objetivo a tangibilização e propagação da cultura da empresa, o departamento de Felicidade. O departamento de felicidade parte do princípio de que, quanto mais se investe nas pessoas e na construção de um ambiente incrível de trabalho, mais elas serão produtivas, pensarão "fora da caixa" e contarão para seus amigos e familiares. O departamento de felicidade, ainda segundo o entrevistado Igor, tem a responsabilidade de comunicação interna, então, tudo que se entende que um colaborador precisa saber, é de responsabilidade do departamento reverberar essa informação internamente, mantendo sempre a forma da Reserva de se comunicar.

Figura 2: E-mail de comunicação interna do departamento de felicidade

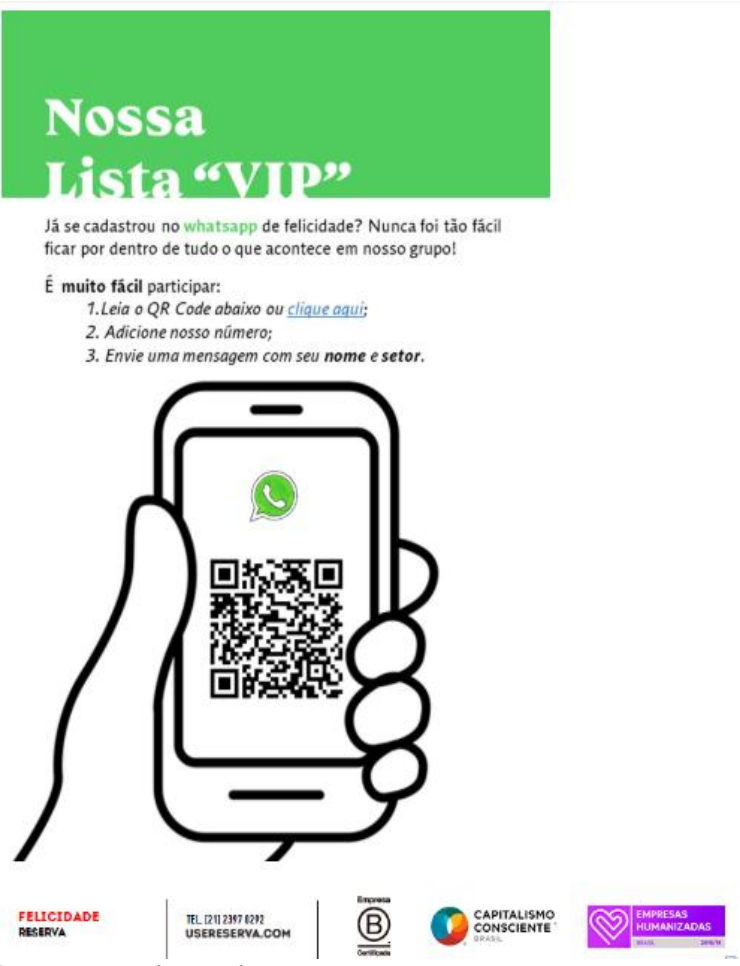

Fonte: Departamento de felicidade (2020)

Segundo a entrevistada Renata Tobias, coordenadora do departamento de felicidade, além da comunicação, o grande papel do departamento de felicidade é encantar os funcionários, criando o máximo de benefícios e parcerias, reconhecendo o trabalho dos colaboradores com premiações, realizando ações internas que promovam o bem-estar social, criando assim "embaixadores da marca", que são apaixonados pelo grupo Reserva, construindo um ambiente de trabalho leve e harmonioso, mantendo os 
funcionários motivados para realizar o trabalho.

De acordo com o analista de escola de Rebeldia Igor Monteiro, o que distingue o departamento de Felicidade de um departamento de endomarketing de uma empresa tradicional, é:

“(..) as ações realizadas no departamento são guardiões do que é
entendido como cultura Reserva. Quando o departamento foi criado lá
atrás em 2015 , a primeira iniciativa do departamento foi fazer uma
pesquisa interna para entender o que era a cultura Reserva para as
pessoas. A Reserva foi entendida como uma empresa inovadora,
família e realizadora de sonhos. Diante desses três pilares que as
pessoas entendiam a Reserva, foram construídos três grandes
programas do departamento de Felicidade, que estavam ligados a
percepção das pessoas sobre a Reserva”

Segundo Igor Monteiro, uma das ações realizadas pelo departamento que tem como objetivo a perpetuação da cultura de inovação na organização é de trazer empreendedores reconhecidos para falar para a empresa sobre a sua trajetória empreendedora e assim, manter a cultura de intraempreendedorismo dentro da Reserva.

Como relatado por Igor Monteiro, os programas e ações criadas pelo departamento de felicidade são desenvolvidos para que haja uma perpetuação da cultura atual da empresa, que é vista pelos colaboradores como uma cultura voltada para a inovação. Dessa forma, pode-se comprovar a teoria abordada no tópico Gerenciamento Cultural no capítulo 2, onde o autor Fleury (1989)defende que para a manutenção da cultura vigente, a empresa investe em desenvolver práticas organizacionais que tem como objetivo manter os valores e hábitos da empresa.

Andando pela sede administrativa da empresa, consegue se observar que existe um layout muito diferente do que se encontra em empresas tradicionais, sendo montado para se ter um ar jovem, descontraído, em um ambiente informal, onde os funcionários trabalham com roupas consideradas antiquadas no meio corporativo. A área de convivência tem uma mesa de sinuca e totó, redes para se descansar, videogames de última geração e mesas utilizadas para reuniões, assim como empresas conhecidas por esses traços de descontração e informalidade como Google, Facebook e Mercado Livre. Segundo Renata Tobias, coordenadora do departamento de felicidade, a decoração da sede tem como objetivo criar um ambiente que as pessoas se sintam livres para imaginar, 
desenvolver e a inovação é uma consequência.

Figura 3: Área Social da Reserva

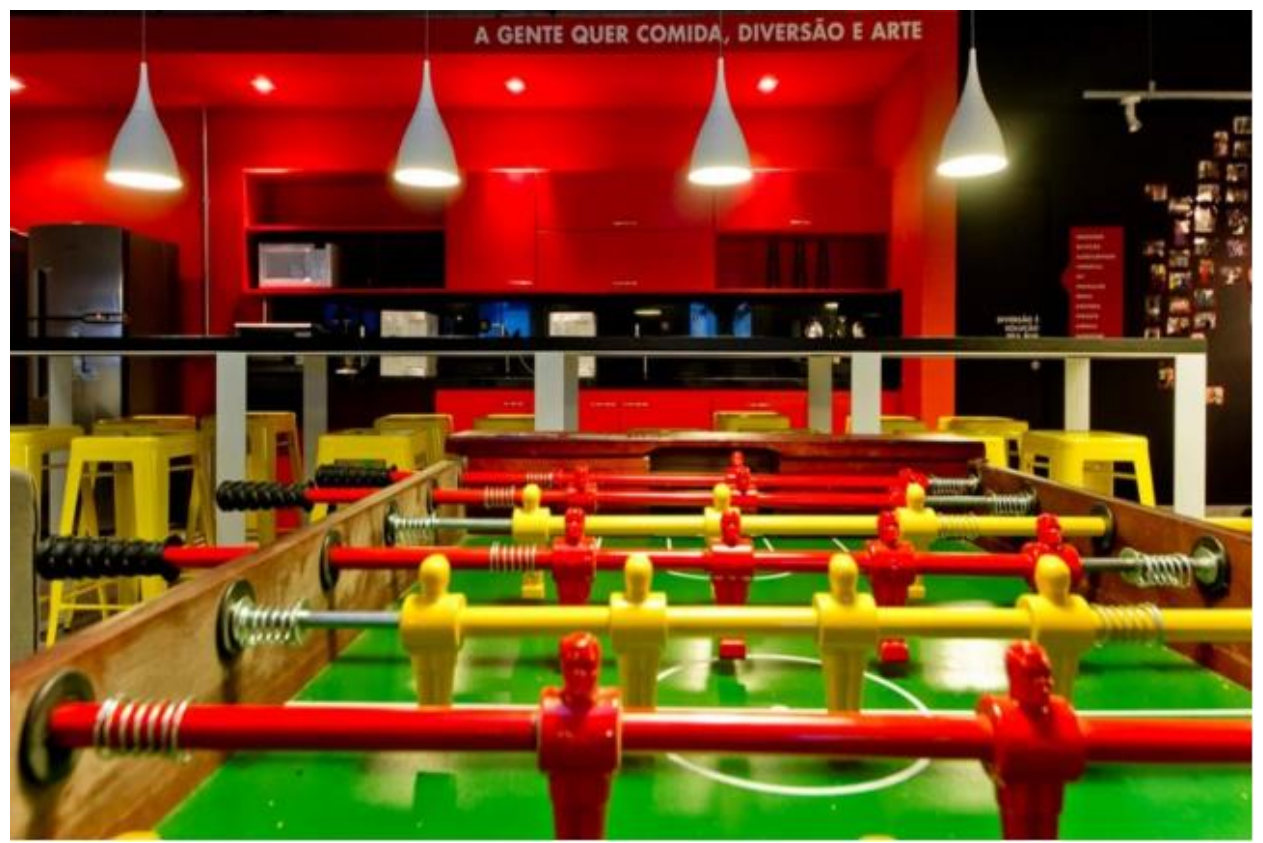

Fonte: Site da Reserva (2020)

A entrevistada Rafaela Lima, analista comercial, relatou sobre 0 ambiente da empresa:

\begin{abstract}
"Parece meio clichê, mas o ambiente da Reserva me faz sentir em casa mesmo, eu posso sair do meu lugar, ir fazer a unha, voltar, me vestir da forma que eu bem entender, sem precisar ter um guarda roupa para trabalhar, outro para sair, então é um ambiente muito tranquilo, muito leve, muito divertido, onde podemos ser nós mesmos. Não preciso ter uma Rafaela do meio corporativo e uma de fora do trabalho, eu posso ser eu mesma."
\end{abstract}

Todos as entrevistas apontaram que o pensamento da empresa é de que existe uma cultura muito forte na organização, e que essa cultura se faz muito presente no dia a dia da empresa, onde os principais aspectos comentados foram o sentimento de pertencimento a um grupo de pessoas, a vontade de se fazer algo diferente do usual e o movimento de inovação. Tal constatação é confirmada pela teoria de Schein (2009) abordada no tópico Cultura Organizacional no capítulo 2 , que versa que a cultura organizacional fornece um sentimento de pertencimento e continuidade aos membros de uma organização. 


\title{
4.3. Autonomia
}

Uma maneira natural de verificar a autonomia que os colaboradores do grupo Reserva têm para dar sugestões e tomar decisões é a partir das reuniões realizadas pelas equipes, onde segundo o entrevistado lan Coutinho, os estagiários da empresa podem falar o que pensam, dar palpites sobre novos projetos e são de fato escutados, suas ideias são sempre levadas em consideração pelas gerências e diretoria e que muitos projetos já saíram de ideias de estagiários. lan cita:

\begin{abstract}
"Desde que entrei como estagiário percebia muito que eu tinha liberdade para não só sugerir, mas também colocar minhas ideias de pé, sem nenhuma trava do tipo... tenho que falar com o gestor, diretor, sócio, com cinquenta vertentes da empresa para poder aprovar algum projeto. Eu lembro claramente que no primeiro ano (eu entrei já no final do ano) a gente fazia uma promoção importante no último mês, que é o mês mais importante para o varejo (dezembro), e sempre foi uma promoção que era quase igual, um compre e ganhe com um item que era tipo um brinde, e a gente resolveu mudar o patamar dessa promoção e fazer parcerias com empresas gigantes, e eu como estagiário, resumindo muito, depois de alguns meses estava tocando uma parceria com a Johnny Walker, tomando todas as decisões do projeto, que foi o produto mais vendido daquele dezembro. Eu, como estagiário, tocando uma parceria com uma multinacional".
\end{abstract}

Como descrito, a autonomia aparece em todos os níveis hierárquicos da companhia, o que, comprova a teoria de Oliveira Junior (2009) visitada no tópico Autonomia do capítulo 2. Tal teoria afirma que, a autonomia em toda a hierarquia é essencial para que exista uma cultura empreendedora. Por outro lado, é natural que para determinados níveis e principalmente para as lideranças, a autonomia seja ainda maior, onde colaboradores podem tomar decisões estratégicas que influenciam a maneira como a empresa opera. Claudia Moraes, diretora de compras e suprimentos, relembra quando entrou na empresa, em 2011:

\footnotetext{
"Eu entrei na Reserva como uma gerente de compras, com o objetivo de construir e reformular todo um departamento de compras, que na época existia. Eu tive total liberdade e autonomia para fazê-lo. Eu fiz, eu mudei inclusive a disposição física das pessoas, eu unifiquei estilo e compras, que eram separados em lugares físicos inclusive. Eu sempre tive muita liberdade disso e, consequentemente, reconhecimento. Eu entrei como gerente, eu virei diretora, eu virei notável, eu virei sócia. E tudo isso foi uma recompensa por cada novidade, estratégia, mudança que eu levava".
}

Reconhecimento, inclusive, é algo bastante comum para os funcionários que se destacam no grupo. A Reserva tem alguns programas de reconhecimento 
para funcionários que tomam decisões acertadas e levam algo de novo para a companhia. Segundo lan Coutinho, toda convenção de vendas, o prêmio mais valorizado da empresa é para um vendedor da companhia que ganha o prêmio "movendo o céu e a terra pelo cliente", onde o colaborador toma uma decisão de fazer algo de diferente pelo cliente, atitude chamada na empresa de "encantamento". Na convenção de vendas de 2019, por exemplo, o vendedor vencedor do prêmio, recebeu na loja um pai com um filho de camiseta do Flamengo. O menino ficou conversando com o vendedor e falou que em breve seria o seu Bar-Mitzvah e que era viciado pelo Flamengo. O vendedor, amigo de um funcionário do Flamengo, decidiu fazer algo de diferente por seu novo amiguinho e conseguiu uma camisa autografada por todos os jogadores e que alguns jogadores fizessem um vídeo para passar no seu Bar-Mitzvah, e entregou para os pais darem na festa para o menino, que ficou extremamente emocionado.

O reconhecimento também é comum para quem traz algo de "notável", para a companhia que possui um programa exatamente com o nome "notáveis". Também em cada convenção de vendas, novos notáveis são nomeados, após uma seleção baseada na contribuição que trazem para a organização, em forma de produto ou serviço inovador com grande impacto para a companhia.

Os notáveis são avaliados semestralmente por três anos, e essa avaliação, cruzada com o resultado da companhia, determina uma nota final por ano. A partir dessa nota, os notáveis são convidados a serem sócios e a quantidade de capital recebidos em ações é proporcional a sua nota. É o caso de Rodrigo Berutti, head que contou sobre projetos inovadores, principalmente se tratando de varejo de moda, para a companhia, que liderou com total autonomia:

\footnotetext{
"A empresa tem um perfil muito empreendedor, caráter muito de start up. E a gente chegou e começou a fazer as coisas que a gente achava que poderia trazer o maior resultado para empresa no curto prazo. E a gente desenvolveu dois grandes sistemas, um é o sistema de push and pull, é a reposição automática, e outra a gente começou a desenvolver as primeiras versões lá do nosso WMS, lá na logística. E cara, esses foram zero direcionados, foi uma ideia nossa olhando os gaps que a empresa tinha. Enfim, então, se a empresa não tivesse esse tipo de cultura e não incentivasse as pessoas a fazerem o que elas acreditam e que possa trazer resultados para a empresa, possivelmente isso não teria nem acontecido. $E$ isso me deu notoriedade, assim como outras pessoas da empresa que estavam envolvidas nos projetos. "
} 
Conforme visto na teoria de Oliveira Junior (2009) nos tópicos Autonomia e Cultura Organizacional orientada ao empreendedorismo no capítulo 2, que afirmam que para que exista uma cultura empreendedora dentro da empresa, é necessário que exista autonomia para tomada de decisões e reconhecimento para decisões acertadas, o que, pode ser observado nas entrevistas que acontece de fato na Reserva. Porém, vale ressaltar que a diretora do Departamento de compras, Claudia Moraes afirma que, algumas vezes, os colaboradores esperam um reconhecimento prematuramente.

\subsection{Inovação}

Dentro da sede Administrativa da empresa, muito se investe em pesquisa para desenvolvimento de novos produtos, busca por novas matérias primas e desenvolvimento de soluções tecnológicas, tanto para seus processos, quanto para seus canais de venda, o que segundo a teoria de Salles (2011) mencionada no tópico Inovação no capítulo 2, é comum para empresas inovadoras.

Priscila Flores, compradora da Reserva, fala que antes de uma coleção ser desenvolvida, o time de estilo e de compras passa meses pesquisando, e como resultado, apenas nessa última coleção de inverno 2020, alguns produtos completamente diferentes do que se tem no mercado foram desenvolvidos. Priscila fala, com orgulho, da linha de produtos resistente à líquidos:

"Ficamos meses e meses pesquisando sobre o algodão, buscando fornecedores, maneiras de conseguir fazer com que desse certo, e conseguimos. Pode cair água, molho shoyo, café, coca, o que for, o tecido repele tudo! A linha resist é um sucesso! " 
Figura 4: Produto da linha resistente a água

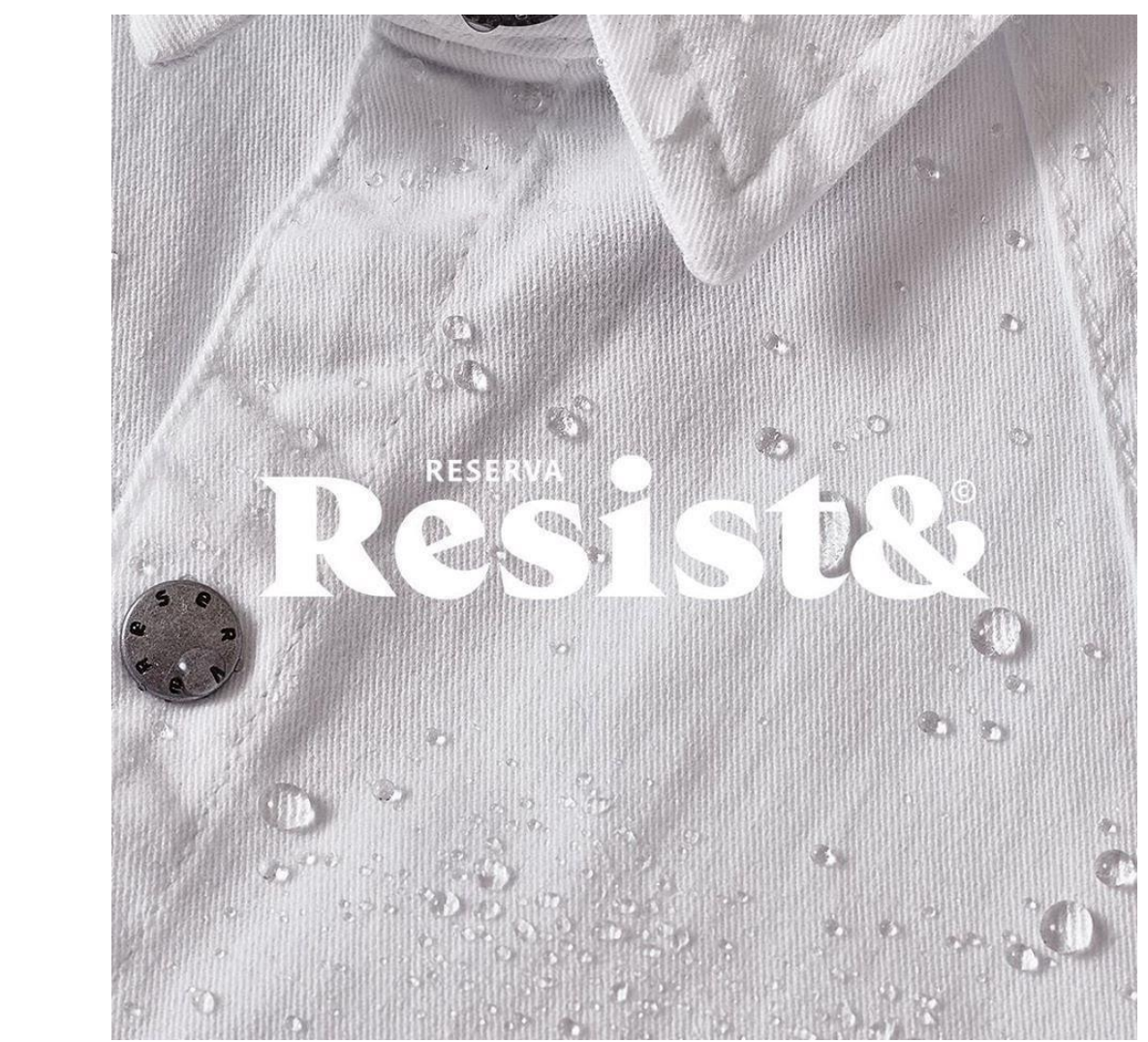

Fonte: Instagram da Reserva (2019)

Os produtos de coleção da Reserva são criados a partir de três pilares: tecnologia, sustentabilidade e funcionalidade. Alguns dos produtos funcionais e tecnológicos, por si só, são grandes inovações para o mercado de moda. Claudia Moraes fala sobre a nova calça da Reserva, vendida para o mercado como "A melhor calça do Mundo":

\begin{abstract}
"Agora acabamos de lançar nossa calça, que é o que se tem de mais moderno. Uma calça de alfaiataria que tem um tecido confortável, quase que esportivo, um tecido confortável à base de poliamida, que ele tem a tecnologia biodegradável, ou seja, já preocupado com a sustentabilidade, ele é antibactericida, por dentro em contato com a pele ele absorve o suor, ou seja, se você saiu do seu trabalho, pegou uma bicicleta e saiu para chegar no teu trabalho, ele vai absorvendo o teu suor, e por fora, se você pegou uma chuva, ele repele a água."
\end{abstract}

Olhando para o mercado e entendendo uma tendência que estava por vir, e atualmente está em alta no mercado, a Reserva criou, em 2015, um serviço de customização de produtos. O "Faça.Vc" surgiu na empresa como uma ferramenta para os clientes customizarem suas camisetas com frases e desde 2017, os clientes podem personalizar com imagens, figurinhas e palavras, e até desenhos feitos no sistema camisetas, bodies para bebês, bolsas e almofadas. 
lan Coutinho relata:

"Acredito que seja uma das provas mais vivas de como a Reserva está à frente do mercado. Um serviço que disponibilizamos em 2015 no nosso site e lojas, vemos hoje, em 2020, diversas marcas começando a fazer. "

Figura 5: Ferramenta para criação de produtos

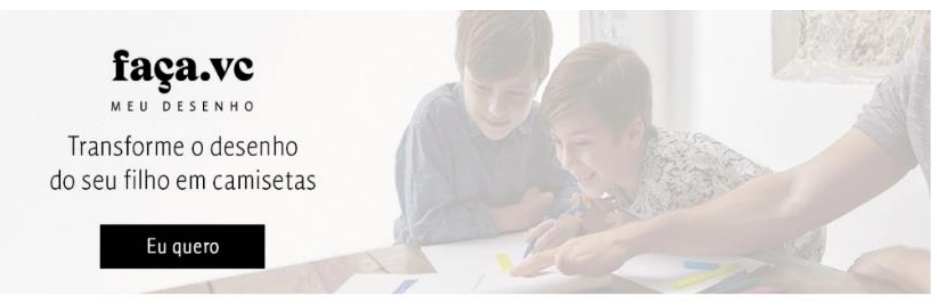

O MELHOR PRODUTO É VOCÊ QUEM FAZ!
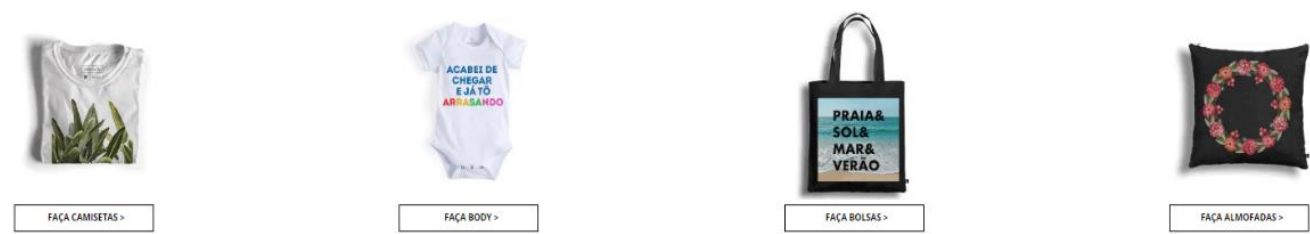

Fonte: Site da Reserva (2020)

A busca por novas tecnologias para seus processos é constante para a Reserva, o que segundo a teoria de Oliveira Junior (2009) vista no tópico Inovação no capítulo 2, é o natural em empresas inovadoras. Desde o atendimento em loja, onde o vendedor imputa dados sobre o atendimento ao cliente em um sistema de ERP, desenvolvido pela companhia, chamado "Now", até o sistema de reposição automática de produtos em loja, chamado de "Repa", são sistemas tecnológicos extremamente avançados, principalmente para o varejo de moda.

Segundo Rodrigo Berutti, head de produtos digitais, a Reserva já recebeu diversas ofertas de compras desses sistemas desenvolvidos para auxiliar os processos da empresa, mas nunca aceitou, por acreditar que de fato, tais produtos geram uma grande vantagem competitiva para a companhia.

Muito antes de se falar em omnichannel no Brasil, a Reserva já estava desenvolvendo o seu sistema para preparar o grupo para esse novo momento de consumo que o mundo vive atualmente. No livro "Rebeldes tem asas", Rony fala que operar a omnicanalidade significa tecnologicamente ter uma visão única do estoque, independentemente de onde ele esteja, para assim, 
minimizar o risco de ter estoque em um lugar e não conseguir entregar um produto para o cliente pois ele está em outro local. Para se trabalhar o omnichannel, a empresa investiu, e investe, muito em soluções tecnológicas e logísticas para atender seu consumidor com o que, como e quando ele desejar. Entrando em uma loja da Reserva, pode-se observar totens interativos para que clientes finalizam suas vendas e recebam seus pedidos em casa.

Como mencionado nas teorias de Salles (2011) e Oliveira Junior (2009) no tópico Inovação no capítulo 2, para ser considerada uma empresa inovadora, a empresa precisa ter uma visão inovadora, buscar o pioneirismo, antecipar tendências futuras do mercado e investir em pesquisa e desenvolvimento, para assim, se obter vantagem competitiva. Todas essas características podem ser observadas na empresa a partir dos diversos exemplos citados que foram comentados nas entrevistas pelos colaboradores, assim como são evidenciadas no livro "Rebeldes tem Asas e no site da companhia. Dessa forma, pode-se concluir a partir da teoria e das evidências que a Reserva é de fato uma empresa inovadora.

\subsection{Capacidade de Assumir Riscos}

O lema da Reserva é errar pequeno para acertar grande. Dois dos entrevistados mencionaram a mesma história que Rony, CEO da empresa sempre fala para os colaboradores do grupo sobre tomada de risco. Igor Monteiro relata:

\footnotetext{
"O risco na Reserva é estimulado dentro de uma realidade de critério, né, não é um risco qualquer. Existe uma lenda que o Rony sempre fala da vitrine cor-de-rosa: se um dia o time de visual merchandising disser que cor-de-rosa vai vender mais, ele não vai poder de o dia para a noite pintar todas as vitrines de cor-de-rosa. Agora, se eles disserem isso, e lançarem uma tese de pintar de cor de rosa a vitrine da loja que menos vende, que não está dando resultado, e gastarem pouco para fazer essa mudança, ele vai ser estimulado a tomar esse risco para poder até confirmar ou não essa teoria, e se confirmada, aí sim, mudaremos as lojas. "Mas e se não vender? " Não tem problema nenhum. Então é uma tomada de risco que é sim incentivada, mas sempre de forma criteriosa."
}

A teoria de Oliveira Junior (2009) vista no tópico Capacidade de Assumir Riscos no capítulo 2 sugere que nas empresas que tem capacidade de assumir riscos, os líderes incentivam que seus colaboradores tomem riscos sem medo 
do insucesso, mas tomando atitudes que calculam tais riscos. No caso da Reserva, pode-se observar que existe esta cultura, e que seus colaboradores são incentivados a tomar riscos pelas lideranças, porém riscos identificados e responsáveis, que não põem em cheque o valor da marca Reserva e nem um valor financeiro considerando impactos significativo na viabilidade do negócio.

Esses riscos incentivados, são estímulos as tentativas, e consequentemente, muitos erros acabam acontecendo. Segundo Clara Farias, estagiária de produtos digitais, o erro é visto com naturalidade e os colaboradores são incentivados a continuarem dando o seu melhor e pensando em projetos "fora da caixa", sempre incentivados a fazer o melhor para não errar. Ao mesmo tempo, é muito importante que no momento do erro, o colaborador não se esconda, e assuma o seu erro, o que é bastante valorizado na Reserva.

A Reserva se utiliza muito da metodologia Minimum Viable Product - MVP (mínimo produto viável em português), que ficou popular a partir do livro "Startup Enxuta", para com pequenos gastos, tanto de tempo, quanto financeiro, consiga se entender a viabilidade de investir em um projeto ou produto. Rodrigo Berutti, head de produtos digitais, que segundo o próprio, é um grande defensor da metodologia MVP, fala que é importante que o gestor dê liberdade para que os colaboradores tomem risco, mas que esteja sempre próximo para auxiliar o seu time:

\begin{abstract}
"Eu incentivo bastante as pessoas a tomarem risco, óbvio que, até por conta do meu perfil, eu participo muito ali do dia a dia, até para ajudar com a minha experiência, eu acho que isso agrega para a empresa, mas cada vez mais eu tento fazer com que as pessoas se sintam donas e enxerguem que aquilo é como se fosse um micro negócio deles, e arriscar faz parte. É óbvio que a gente é super controlado nas questões orçamentárias e etc., então a gente está acompanhando as coisas, mas sim, entendo que a gente incentiva as pessoas a arriscaram, até porque eu acho que a gente tem, como falado um pouquinho antes, uma cultura intraempreendedor muito forte."
\end{abstract}

A teoria de Salles (2011) abordada no tópico Capacidade de Assumir Riscos no capítulo 2 aponta que em culturas orientadas ao empreendedorismo, a empresa apoia os líderes ou membros da organização que tenham falhado em um novo projeto, e trazendo essa realidade para a Reserva, pode-se identificar casos de lideranças que não tiveram sucesso em alguma de suas empreitadas, foram mantidos na empresa e atualmente tem mais responsabilidades dentro da companhia, é o caso do diretor de novos negócios, relatada por Igor Monteiro: 


\begin{abstract}
"Exemplo disso está inclusive no caso lá de novos negócios, na época das camisetas da UseHuck, para mim é um bom exemplo o quanto a empresa entende também o erro quando ele acontece. Então foi um erro que aconteceu, que provocou inclusive o fim de uma linha de produtos, mas que não custou lideranças, ou times, e foi aquela mesma liderança daquele projeto continuou e assumiu a liderança de outros projetos dali para a frente, então é um exemplo de como a gente lida com esse erro."
\end{abstract}

Como se pode perceber a partir dos relatos dos entrevistados, o risco faz parte do cotidiano dos colaboradores da Reserva, porém, a teoria apresentada de Salles (2011) no tópico Capacidade de Assumir Riscos afirma que empresas com grande capacidade de assumir riscos decidem entrar em projetos, criar novos produtos mesmo com o risco de uma grande perda financeira, o que não é a realidade da Reserva, onde segundo os colaboradores entrevistados, são orientados a realizar seus projetos a partir de MVPs, reduzindo ao máximo o custo dos projetos, evitando assim possíveis perdas financeiras significativas da empresa.

\title{
4.6. Proatividade
}

A teoria de Oliveira Junior (2009) apresentada no tópico Proatividade do capítulo 2 afirma que a proatividade está relacionada a introdução de novos produtos, serviços antes dos outros competidores, antecipando tendências. Comprovando o que o colaborador lan Coutinho, analista de trade marketing relatou em sua entrevista, que desde o seu lançamento no mercado, em 2006, a Reserva investe em um conceito de loja e atendimento totalmente diferentes do que se via no mercado. Desde videogames a cervejas em loja, a chamada "experiência Reserva", que tem como objetivo transformar o conhecido ponto de venda em ponto de encontro, é um exemplo de serviço da Reserva que, atualmente é bastante replicado pelos competidores. Ian Coutinho conta:

\footnotetext{
"A Reserva começou a servir cerveja em loja, transformar o ponto de venda em ponto de encontro, que é o que a gente mais fala, daqui a pouco várias outras marcas, você chega e tem chopp, cerveja, coisas que a Reserva colocou há 10 anos atrás. E é engraçado como a gente conseguiu acompanhar esse movimento, vendo algumas lojas começando a fazer e atualmente tem várias".
}

Não só pela "experiência Reserva", mas também por diversos produtos lançados e copiados no mercado nacional, pode-se dizer que a Reserva é vista 
como influenciadora em seu mercado, onde seus funcionários dizem que acreditam que os passos da Reserva são vistos por todos no ecossistema.

Como visto no tópico Proatividade do capítulo 2, a proatividade e a inovação devem caminhar juntas, uma vez que empresas proativas tem vontade e a ambição de aproveitar novas oportunidades para criar novos produtos, e os funcionários são orientados a não deixar de olhar para o que está em volta e abraçar as oportunidades, o que pode ser comprovado que de fato acontece na Reserva com os exemplos citados pelos colaboradores.

Um desses exemplos é o caso da Camiseta QrCrush, onde o colaborador João Martinez, ao ver uma camiseta criada por um cliente na ferramenta Faça.Vc, identificou uma grande oportunidade de inovação. Era uma camiseta com um simples QrCode, que poderia passar e ser simplesmente mais uma camiseta, das muitas que são feitas diariamente na ferramenta. Mas ao olhar para a camiseta, João pensou: "O Carnaval está vindo aí, dá para fazer algo muito legal".

O time da Reserva entrou em contato com o cliente, perguntou se poderia usar a sua ideia, e assim, nasceu a "Camiseta QrCrush", onde entrando na ferramenta o cliente cadastra o seu Instagram e cria uma camiseta com um link para a sua página na rede social. A ideia foi um sucesso e a camiseta foi um dos produtos mais vendidos do mês pré-carnaval no site da empresa.

Figura 6: Camiseta QrCrush

$$
\text { qr crush }
$$

Neste Carnaval, dê matches com sua camiseta.

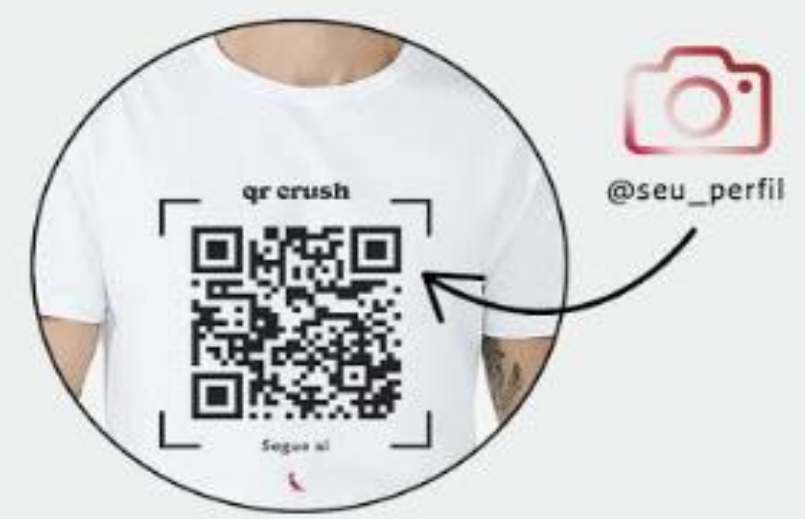

Fonte: e-mail marketing da Reserva (2020) 
Quando o assunto é velocidade de se adaptar às mudanças, componente essencial para empresas proativas segundo a teoria de Oliveira Junior (2009) no tópico Proatividade no capítulo 2, as opiniões dos entrevistados apontam que acreditam que seja extremamente natural na companhia, que as coisas mudam de uma hora para outra e que a empresa como um todo consegue se adaptar, conforme comentado por Renata Tobias:

"Tudo é muito rápido e se você não tem essa possibilidade, essa facilidade de se adaptar à mudança, talvez aqui não seja o lugar para você trabalhar. E como falei, eu acho que a empresa tem um ritmo muito de start up, inovador, de mudar. Deu certo, "vamos, vamos lá", não deu certo "vamos virar chave, já vambora, continua, segue o baile."

No relato de Renata é possível identificar características vistas na teoria de Cultura Organizacional Orientadas ao Empreendedorismo, que segundo os estudos de Dolabela (2008) afirmam que a velocidade, dinamismo que as coisas acontecem tem como consequência a rápida tomada de decisão, o que fortalece a mentalidade de empreendedorismo dentro da organização.

Analisando as entrevistas dos colaboradores apresentadas acima, podese perceber a partir dos conceitos apresentadas nos tópicos Proatividade e Orientação Empreendedora, que apontam o pioneirismo na criação de novos produtos, serviços e antecipação de tendências, além da facilidade de se adaptar a mudanças como dos principais aspectos para se ter uma cultura empreendedora proativa, que a Reserva é uma organização bastante proativa no mercado que está inserida.

\subsection{Competitividade Agressiva}

Conforme visto na teoria de Salles (2011) apresentada no tópico Competitividade Agressiva no capítulo 2, a competitividade agressiva é uma conduta de sobrevivência e posicionamento estratégico frente aos competidores buscando manter ou chegar a liderança no mercado de atuação. Um dos comportamentos de empresas agressivas é a cobrança por atitudes rápidas e estratégicas dos colaboradores.

A cultura da Reserva, como já falado, é de tomadas de decisões rápidas 
e de botar novos projetos com agilidade no mercado, através da metodologia MVP. Uma das frases que Rony sempre fala para os colaboradores do grupo é "Nasceu perfeito, nasceu tarde", que quer dizer que se a empresa demora muito a lançar seus novos produtos ou serviços, algum competidor pode lançar primeiro e pegar o mercado para si. Dessa forma, a empresa deve lançar rapidamente seus novos projetos e seguir aperfeiçoando a partir do feedback de seus clientes. Renata Tobias comenta sobre a agilidade da empresa:

\begin{abstract}
"A capacidade de se inventar, de criar, de "não deu certo, faz de novo, faz de uma outra forma", tipo de um dia para o outro, sabe? Teve uma ideia hoje de manhã daqui a pouco todo mundo se mobilizou e já está rodando a noite. É surreal realmente, isso me deixou muito impressionada e eu acho que quem realmente está engajado carrega muita energia."
\end{abstract}

Outro aspecto importante para empresas agressivas, é a utilização feedbacks de seus produtos e serviços para tomadas de decisões. Após cada venda, seja em uma loja ou no site da empresa, o cliente recebe um e-mail para avaliar tanto o atendimento e experiência, quanto o produto. Os dados enviados pelos clientes são utilizados para diversas ações, relata lan Coutinho:

\begin{abstract}
"Primeiro, falando sobre o nosso principal serviço, o atendimento: Quando um atendimento recebe uma avaliação ruim, criamos um plano de ação com o vendedor, ele é chamado para conversar, para entendermos o que está acontecendo, se precisa de alguma ajuda, e pensar em como melhorar. Assim como quando a avaliação é muito boa, ele é exaltado. [...] Sobre produto, fazemos diversas ações, e uma recente que foi muito legal, pegamos a referência da "Amazon 4 stars", Ioja em Nova York onde eles expõem apenas livros com avaliação acima de 4 (sobre 5) e trouxemos para a nossa realidade, criando uma área das nossas lojas apenas para produtos com classificação de 4 para cima. Por mais que não tenhamos a tecnologia que a Amazon tem, a gente tem a iniciativa que a Amazon tem, ou mais até, e a gente foi lá e colocou de pé com metade ou $1 / 3$ ou menos da infraestrutura, e colocamos de pé ali numa área da loja e deu super certo. Foi um projeto com base $100 \%$ em feedback de cliente."
\end{abstract}

Os clientes da Reserva também são muito escutados nas redes sociais da companhia, e assim, a empresa cria novos serviços. A Reserva fez uma pesquisa em seu Instagram sobre quais assuntos os seus seguidores gostariam de ver nas redes da empresa, e assim, surgiu a "TV Reserva", programa de lives diárias nos meses de abril e maio de 2020, trazendo debates sobre empreendedorismo, gastronomia, moda e até aulas de exercícios físicos com convidados que tem grande relação com os clientes da empresa. Dessa forma, reforça a estratégia de marketing da companhia, de manter os seus clientes sempre muito próximos, o que segundo a teoria de Oliveira Junior (2009) 
apresentada no tópico competitividade agressiva no capítulo 2, o investimento em marketing inovador é de extrema importância para empresas agressivas. O departamento de marketing da Reserva é chamado de voz de marca, e é responsável pela comunicação da Reserva para o público. As campanhas da empresa são conhecidas por serem totalmente diferentes do que o mercado de moda historicamente traz, segundo lan Coutinho:

\begin{abstract}
"Óbvio que as nossas campanhas de marketing historicamente são inovadoras, são diferentes, provocam num bom sentido. $E$ a concorrência sempre acompanhou e sempre olhou com olhos de cara "como é que eles pensaram nisso"? E aí vai desde o famoso vídeo do assalto, que quando assaltaram uma loja viram uma campanha comercial, sem gastar 1 real, um funcionário de TI que pegou as câmeras de gravação e transformou em um comercial que bombou, explodiu no mundo inteiro esse vídeo, até campanhas super bem pensadas e bem planejadas, com a última "livre para ser", em que a gente juntou pessoas de diferentes perfis, diferentes hábitos, rostos, sexos, enfim, todos os perfis possíveis, para mostrar que a Reserva veste todo mundo, que a Reserva não é uma marca de um público só.
\end{abstract}

Figura 7: Campanha publicitária da Reserva a partir de um assalto

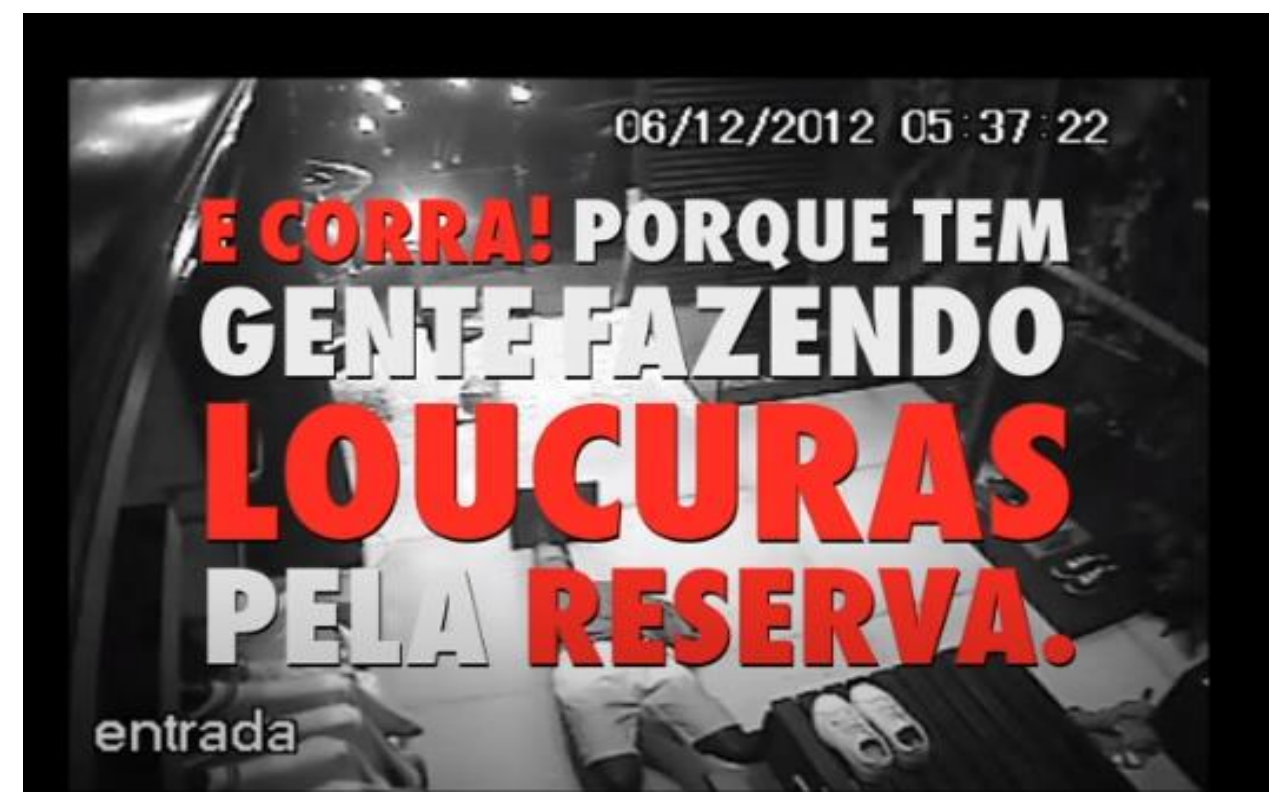

Fonte: Youtube da Reserva (2017)

Portanto, os aspectos vistos nas teorias de Salles (2011) e Oliveira Junior (2009) vistas no capítulo 2, apontam características como o marketing inovador, a velocidade para ação e reação e a utilização de feedbacks dos clientes são facilmente identificados nas campanhas publicitárias e nas entrevistas dos colaboradores, que apresentaram diversos exemplos que apontam que a Reserva é uma empresa competitiva agressiva, e que isso de fato, é vivenciado 
pelos colaboradores da empresa.

\subsection{Formação de Parceria}

Empresas empreendedoras têm o hábito de formar parcerias de longo prazo com seus fornecedores, consumidores e empresas que possuem uma identificação consigo, buscando a proteção e o bem-estar de seus parceiros para juntos, terem vantagens competitivas e atingirem seus objetivos estratégicos, aponta a teoria de Oliveira Junior (2009) apresentada no tópico Formação de Parcerias no capítulo 2.

No caso da Reserva, é bem importante mencionar que $95 \%$ da produção da é feita em território nacional, mesmo isso gerando um custo de produção muito maior, se comparado ao custo de produzir em países asiáticos. O livro "Rebeldes tem asas" conta que os $5 \%$ que são produzidos fora do país, é por não ter uma indústria que consiga atender o volume necessário pela Reserva para determinados produtos.

Segundo Cláudia Moraes, a empresa tem a postura de manter grande parte da produção no país para valorizar a cadeia nacional e seus fornecedores, onde muitos estão com a Reserva desde o começo, trabalham exclusivamente para a empresa e crescem junto com a empresa:

"A gente tem parceiros por exemplo de 13 anos, desde o primeiro dia
de vida da Reserva esse fornecedor até hoje está lá dentro da Reserva.
A gente não tem fornecedores espalhados, muito variado, a gente é
concentrada em menores, mas que a gente tem dá uma garantia
fabricação. E eles mesmo investem bastante para aguentar o nosso
crescimento. Então a gente conversa muito sobre todo o nosso
crescimento que a gente quer fazer no futuro e eles acabam investindo
junto com a gente, para ter condições de nos atender. Isso é a melhor
garantia que um fornecedor pode querer, posso te garantir isso, essa
tranquilidade, então é muito legal."

Segundo Alan Abreu, responsável pelo Departamento de Sustentabilidade do grupo, a Reserva possui dois certificados que garantem a responsabilidade que a companhia tem tanto com os seus parceiros e fornecedores, quanto com o meio ambiente, são eles o Sistema B e a ABVTEX.

O sistema B é uma certificação que garante que a Reserva tem atitudes socioambientais corretas, que valorizam toda a cadeia. Já o selo ABVTEX, 
representa que a empresa implementa as melhores práticas de compliance com seus fornecedores, a favor do uso do trabalho digno na cadeia produtiva de moda.

Com relação a seus clientes, já foi abordado algumas vezes no trabalho que a Reserva preza por estabelecer relacionamentos de amizade, e isso acontece por diversas ações na companhia. Clara Farias contou sobre uma:

"No dia do aniversário ligamos para o cliente, damos parabéns e nem mencionamos nada sobre venda, e os clientes ficam: Cara, como assim eles lembraram do meu aniversário? Isso é muito mais impactante para um cliente do que simplesmente ligar para falar: Quer comprar uma camisa?"

Já Diego Portugal, falou sobre como o sistema Now auxilia na construção de relacionamentos entre a marca e os consumidores:

\begin{abstract}
"Durante o atendimento eu vou conversando com o cliente, entendendo para o que ele está comprando, qual é a ocasião, se é algum presente, e quando o cliente sai da loja, anoto tudo no Now. Um tempo depois, ligo para o cliente e pergunto sobre a ocasião e se o produto funcionou bem, por exemplo: "E aí Marcio, como foi a festa do Luiz? A camisa fez sucesso?" Ou "Oi Luiza, como foi a viagem de dia dos namorados? O João gostou do presente? " E os clientes ficam muito felizes, sentem que estamos genuinamente interessados neles, e isso gera muita confiança e consequentemente, fortalece os relacionamentos, então, é uma troca muito gostosa"
\end{abstract}

Em relação a realização de parcerias para desenvolvimento de produtos, no final de 2018, a Reserva criou a sua célula colaborativa, a Rsv+, responsável pela criação de colabs (linhas de produtos em colaboração entre duas ou mais empresas) e desde então, mensalmente lança uma linha de produtos com uma marca, empresa ou celebridade que tenha sinergia com a cultura da Reserva. Algumas marcas reconhecidas mundialmente fazem parte do portfólio do da Rsv+, tais como New Balance, Gato Felix, Umbro, NBA, entre outras.

Segundo Pedro Parreira, head de criação da Rsv+, a estratégia da Rsv+ é de criar valor para ambas as marcas ao desenvolver novos mercados, além de testar novos produtos que podem vir a ser produtos de coleções da Reserva:

"A Rsv+ nasceu para trazer aquele jovem que ainda não tinha uma identificação forte com a Reserva, que ainda não era nosso consumidor, mas ao ver as nossas linhas com marcas tão consagradas, com um estilo de produto mais jovem, street wear, começa a consumir os nossos produtos. Assim como nossos clientes começam a consumir a marca parceira, então, é uma relação de ganha-ganha." 
Figura 8: Produto da coleção colaborativa entre Reserva e New Balance

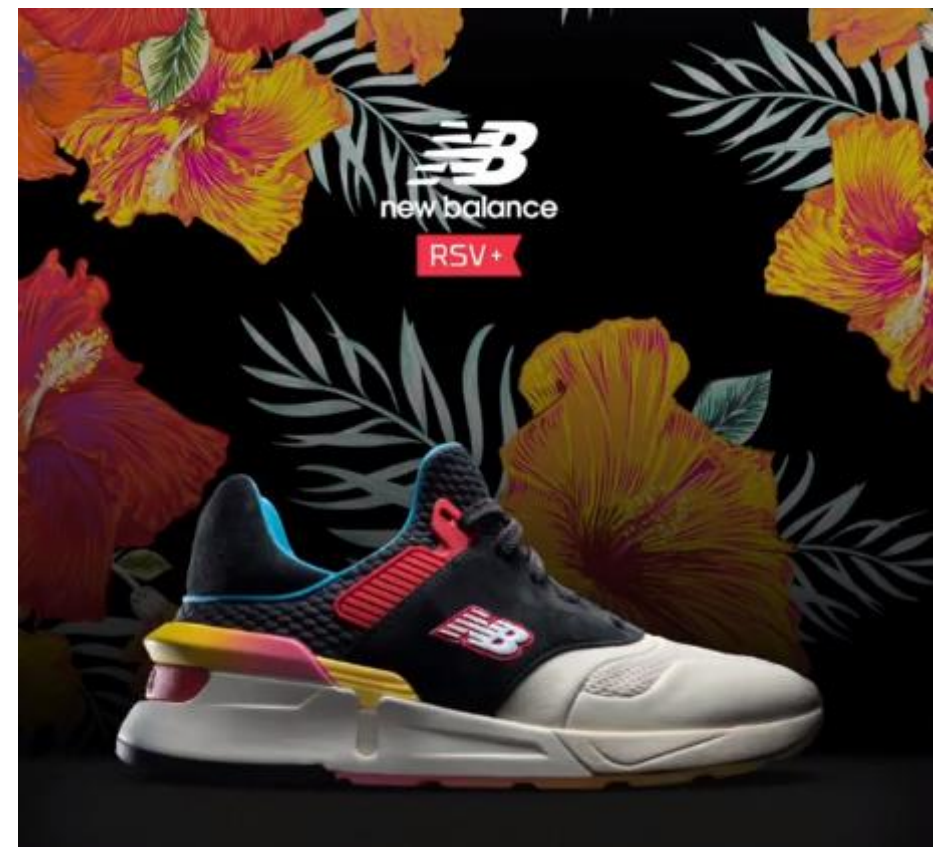

Fonte: Instagram da Rsv+ (2020)

Nas entrevistas dos colaboradores, pode-se observar que a Reserva preza muito pelas suas parcerias que envolvem todo o seu ecossistema, passando por fornecedores, clientes e parceiros estratégicos, para assim, poder obter vantagem competitiva, o que segundo as teorias de Salles (2011) e Oliveira Junior (2009) apresentadas no capítulo 2, é essencial para empresas empreendedoras.

\subsection{Orientação para o Mercado}

Conforme visto no tópico Orientação para o mercado no capítulo 2, empresas orientadas ao mercado tomam ações buscando o aumento da fidelização de clientes. Como já mencionado neste trabalho, a Reserva tem diversas atitudes voltadas para a fidelização da sua base de clientes. $O$ atendimento em loja da empresa, voltada para uma experiência humanizada, segundo Diego Portugal, é um dos motivos dos clientes voltarem às lojas e consequentemente, acabarem comprando novamente:

\footnotetext{
"A gente faz o cliente se sentir bem na loja, e ele estando confortável, vai voltar, porque ele sabe que vai encontrar um bom bate papo, uma boa troca, e ele acaba comprando novamente"
}

Diego Portugal falou também sobre os "encantamentos" feitos em loja, e 
como ele tem o poder de fidelizar o cliente:

"Eu volto mais uma vez no lance do encantamento, vou dar um exemplo: Eu perguntei para o cliente, "Você toma cerveja? " "Não, não gosto de cerveja", aí eu falei "fulano", eu era vendedor, "faz um favor para mim? Toma aqui", fui na caixa, "me empresta aqui", "ah, mas para quê? ", "depois eu explico para o gerente", que não estava lá na hora; "compra lá uma taça de vinho para mim". Era 25 reais a taça de vinho. O cara contou isso para o resto da vida dele."

O marketing é essencial para a fidelização de clientes, pois reforça a identidade da empresa para seus clientes, criando valor e gerando relacionamento. A Reserva possui um time, dentro do departamento de marketing digital, responsável pelo CRM - Customer relationship management, para garantir que um cliente, após comprar na empresa, seja impactado de diversas maneiras e continue em contato com a empresa, segundo Clara Farias:

\begin{abstract}
"O time responsável pela volta dos clientes é o de CRM. Eles têm diversas ações, com diversas réguas comerciais para fazer que haja a recompra e que o nosso cliente esteja sempre em contato conosco. Então, eles são responsáveis por mandar e-mail marketing, remarketing, SMS, entre outros, que gerem engajamento com a nossa base atual. O time de SAC também está dentro do CRM, pois na Reserva, o SAC não tem apenas o papel de resolver problemas com as compras de clientes, mas também ser ativo no engajamento dos clientes"
\end{abstract}

O Departamento de Marketing também é responsável por entender o que de fato os clientes da empresa procuram, quais são as suas necessidades, assim como de passar essas informações para o time de produtos, que analisa a possibilidade do desenvolvimento do produto ou da linha de produtos, Ian Coutinho.

Outro aspecto importante para empresas orientadas ao mercado, segundo a teoria de Oliveira Junior (2009) apresentada no capítulo 2, é estar sempre atenta às tendências de mercado e estar de olho às ações dos concorrentes no mercado. lan Coutinho conta que a empresa sempre está de olho no que o mercado está fazendo, e principalmente, o mercado internacional:

"Em nível de conceito de marca, produto e identidade visual, eu vejo o tempo todo como referências, no setor por exemplo de voz de marca, que é o nosso branding, várias referências internacionais e de outras marcas para trazer para a nossa realidade. Mas, não de concorrência em si, em referências que a gente tem, e aí principalmente marcas internacionais que a gente admira, a gente está sempre antenado e vendo o que está acontecendo"

Por outro lado, lan Coutinho relata que dentre os competidores de moda nacional, apesar de acreditar que a empresa está sempre observando os passos 
da concorrência, a Reserva é muito mais vigiada do que de fato vigia, pois, segundo ele, a Reserva está sempre a frente:

"Olhando aqui para as lojas do lado que concorrem com a gente, eu acho mesmo que a Reserva está sempre um passo à frente e vejo muito mais o contrário do que de fato a gente indo lá seguir. Mas é claro que é muito importante estarmos antenados ao que está acontecendo no mercado, estamos sempre de olho e observando, mas acredito que de fato, somos mais observados de perto, do que observamos.

Ainda segundo lan Coutinho, a Reserva está sempre em busca da criação de produtos a partir de tendências de mercado, e ressalta que hoje em dia, é importante estar atento não apenas a marcas, mas também a influenciadores. lan comenta sobre o desenvolvimento de um produto a partir de referências vistas na internet, e como o produto repercutiu de forma positiva, gerando muitas vendas:

"A gente já viu um chinelo super inovador que escreve na areia. A gente viu uma foto disso, um chinelo que tinha uma marca que quando o chinelo pisava na areia saía marcado o que estava escrito, e não era nem de uma marca, era um casal de blogueiros. A gente segue porque mal ou bem hoje muitas das tendências não vêm da marca, vêm de pessoas influentes, e aí a gente vendo que fizeram o chinelo, se não me engano que tinha o nome do casal, que acabou o casório e todo mundo convidado tinha esse chinelo para sair na praia lá e escrevendo o nome do casal na areia. O chinelo tinha uma marca na sola e aí a aí a gente pensou "dá para criar uma coisa aí", e a gente se juntou com a Johnny Walker para colocar uma parceria com eles para que eles tenham o slogan de "Keep Walking" na areia, para que ficasse lá escrito na areia o "Keep Walking", que embaixo do chinelo tivesse essa marca. O produto saiu em diversas mídias espontâneas, gerou uma repercussão gigantesca, além de ter sido um fenômeno de vendas. " 
Figura 9: Chinelo com a marca "Keep Walking" da parceria com a Johnnie Walker

Fonte: Instagram da Reserva (2020)

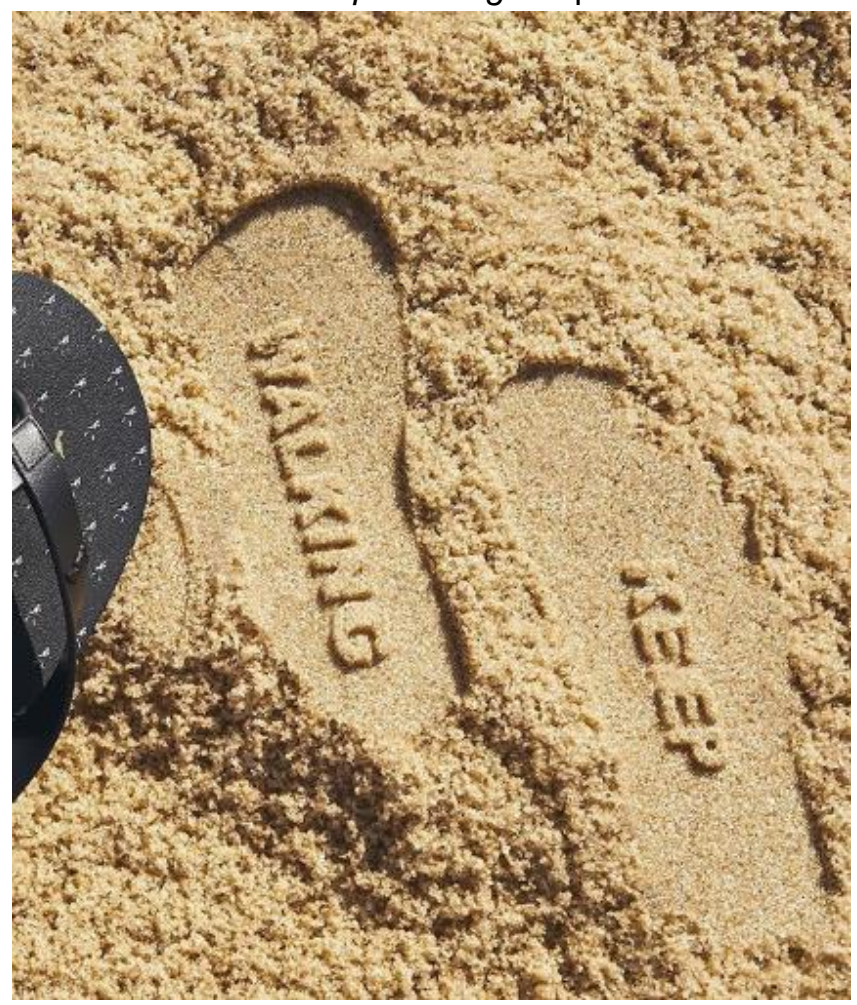

A teoria de Oliveira Junior (2009) apresentada no tópico Orientação ao Mercado aponta que o cliente e suas necessidades são o foco de empresas orientadas ao mercado e que empresas orientadas aos clientes são empreendedoras por criarem novos produtos a partir da necessidade de seus clientes.

O que pode-se observar a partir das entrevistas é que os aspectos mencionados na mesma teoria apresentada são de fato abordados pelos colaboradores, como a atenção ao que os concorrentes estão fazendo, as tendências que surgem, o foco no marketing e principalmente, a orientação para o cliente, então, pode-se concluir que a Reserva é uma empresa orientada para o mercado. 


\section{Conclusão}

O presente estudo teve como principal objetivo explorar a existência de uma cultura organizacional orientada ao empreendedorismo na empresa de moda Reserva.

Inicialmente o estudo revisou a literatura a partir de teorias como empreendedorismo de Schumpeter (1982) e Sheparo (2004), cultura organizacional de Schein (1992) e Mintzberg (2000), a relação entre a cultura organizacional e a orientação empreendedora de Oliveira Junior (2009) e Salles (2011), abordando também o gerenciamento cultural com as teorias de Tomei (2002) e Fleury (1989).

Para tal foi realizado um estudo de caso do Grupo Reserva, baseado em pesquisa exploratória e descritiva, que utilizou o método qualitativo, cujos procedimentos de coleta de dados abrangeram pesquisas do tipo bibliográficas, documentais e a realização de entrevistas abertas, suportadas por um roteiro de entrevista que foi aplicado com 12 pessoas da organização, nos diversos níveis e áreas da organização e com tempos de atuação distintos.

A partir do conteúdo apresentado e das entrevistas realizadas, foi possível compreender como as dimensões de culturas orientadas ao empreendedorismo apresentadas por Oliveira Junior (2009) e Salles (2011), se fazem presentes na Reserva e como afetam o dia-a-dia dos colaboradores do grupo.

Os relatos dos entrevistados demonstraram um pensamento uniforme entre os colaboradores da empresa, que dizem vivenciar os valores da organização e o seu propósito de existir, e dessa forma, pode-se concluir que a Reserva tem uma cultura forte, que se faz bastante presente entre os colaboradores. O gerenciamento dessa cultura é feito através do departamento de felicidade para que haja a perpetuação da cultura atual, que é considerada pelos colaboradores como voltada para a inovação.

Das sete dimensões propostas pelos autores Oliveira Junior (2009) e Salles (2011) como indicadoras de culturas orientadas ao empreendedorismo, 
os relatos dos colaboradores e o conteúdo apresentado, pode-se concluir que seis delas se fazem muito presentes no dia-a-dia da organização, são elas:

- Autonomia: existe autonomia em todos os níveis hierárquicos e existe reconhecimento para decisões acertadas na Reserva.

- Inovação: a Reserva tem uma visão inovadora, busca o pioneirismo, antecipa tendências do mercado e investe em pesquisa e desenvolvimento.

- Proatividade: A Reserva busca criar novos produtos e serviços antes dos competidores de mercado, e muitas vezes, esses produtos se tornam tendências. Além disso, os colaboradores, e consequentemente, a empresa tem facilidade em se adaptar a mudanças.

- Competitividade Agressiva: A Reserva investe em marketing inovador, utiliza feedbacks dos clientes para a criação de produtos e tem agilidade para ação e reação quando encontra oportunidades.

- Formação de Parcerias: A Reserva preza muito pelas suas parcerias e têm diversas ações para fortalecer os vínculos de longo prazo, abrangendo fornecedores, clientes e parceiros estratégicos como outras marcas.

- Orientação ao mercado: A Reserva é atenta ao que os concorrentes estão fazendo, as tendências que surgem e é voltada para o seu cliente.

A única dimensão que, apesar dos colaboradores afirmarem também ser presente em seus cotidianos, não se pode evidenciar, a partir da pesquisa é a capacidade de assumir riscos, pois os colaboradores, incentivados pelos empreendedores, não têm o hábito de tomar riscos que podem acarretar em grandes perdas financeiras.

Vale ressaltar que, as teorias apontaram que para ser, de fato orientado ao empreendedorismo, as sete dimensões não necessariamente precisam estar $100 \%$ presentes na organização.

Dessa forma, pode-se concluir que a Reserva é uma empresa que tem uma cultura forte e orientada ao empreendedorismo, pois das sete dimensões indicadoras, seis são bastante vivenciadas pelos funcionários da organização. 


\subsection{Sugestões e recomendações para novos estudos}

Este trabalho teve como objetivo investigar a cultura organizacional da empresa Reserva, identificando assim, uma cultura inovadora, orientada ao empreendedorismo.

Diversas empresas vêm se destacando no mercado com propostas de relacionamento com seus colaboradores e clientes que impactam em culturas organizacionais inovadoras, e nesse contexto, outros estudos sobre a experiência dessas empresas se tornam bastante pertinentes. A Stone, a Ambev e NuBank são exemplos de organizações que vem ganhando cada vez mais notoriedade em seus mercados pelo fortalecimento de sua cultura interna, recomendando-se a sua análise como forma de aprofundamento no tema tratado nesse trabalho. 


\section{Referências Bibliográficas}

SCHEIN, E. H. Cultura organizacional e liderança. São Paulo: Atlas, 2009

SCHUMPETER, J. A. Teoria do desenvolvimento econômico: uma investigação sobre lucros, capital, crédito, juro e o ciclo econômico. São Paulo: Abril Cultural, 1982

DOLABELA, F. Oficina do Empreendedor: a metodologia de ensino que ajuda a transformar conhecimento em riqueza: 1ํㅡㄹ ed. São Paulo: Editora Cultura, 1999 DRUCKER, P. F. A Nova Era da Administração. São Paulo: Pioneira, 1992

FLEURY, M. T. L. O desvendar da cultura de uma organização: Uma discussão metodológica. São Paulo: Atlas 1989

GIL, A.C. Métodos e técnicas de pesquisa social. 5. ed. São Paulo: Atlas, 2007

GOVNDARAJAN, V. Recognize Intrapreneurs Before they Leave. Harvard Business Review, 2013. Disponível em: $<$ https://hbr.org/2013/09/recognize intrapreneurs >. Acesso em 02 jun.2020

HIRSICH, R. D.; PETERS, M.P. Empreendedorismo. 5.ed. Porto Alegre: Bookman, 2004

HORTON, P. B.; HUNT, C. L. Sociologia. São Paulo: McGraw-Hill do Brasil, 1980

LEITE, R. Reserva é a única brasileira em lista das mais inovadoras da Fast Company. Mundo do Marketing, 2015. Disponível em: < https://www.mundodomarketing.com.br/ultimas-noticias/32820/reserva-e-unicabrasileira-em-lista-das-inovadoras-da-fast-company.html> Acesso em: 04 mai.2020

MILLER, D. The correlates of entrepreneurship in three types of firms. Management Science, v. 29, n.7, 1983.

OLIVEIRA JUNIOR, A. B. O impacto da orientação empreendedora na performance das empresas brasileiras: Evidências de um estudo híbrido. 2009. Fundação Getúlio Vargas, Rio de Janeiro, 2009

PUGLIESE, S. Rebeldes tem Asas. $1^{\text {a }}$ ed, Rio de Janeiro, Sextante, 2017

ROBBINS, Stephen P. Comportamento Organizacional. 11‥ Ed- São Paulo: Pearson Prentice Hall, 2005

SALES, M. D. Tipologia de Cultura Organizacional: Proposta de processo de taxionomia da cultura organizacional de uma empresa com base na orientação empreendedora dos líderes; Campo Limpo Paulista-SP: FACCAMP, 2011

SEBRAE. Anuário do trabalho. Portal Sebrae, 2013. Disponível em: $<$ https://www.sebrae.com.br/Sebrae/Portal\%20Sebrae/Anexos/Anuario\%20do 
\%20Trabalho\%20Na\%20Micro\%20e\%20Pequena\%20Empresa 2013.pdf> Acesso em: 08 mai.2020

SCHEIN, E. H. Cultura organizacional e liderança. São Paulo: Atlas, 2009

SCHUMPETER, J. A. Teoria do desenvolvimento econômico: uma investigação sobre lucros, capital, crédito, juro e o ciclo econômico. São Paulo: Abril Cultural, 1982

STONER, J. A. F.; FREEMAN, R. E. Administração. Rio de Janeiro: PrenticeHall do Brasil, 1995

TOMEI, P. A. A gerência da cultura como ferramenta de competitividade. Rio de Janeiro, PUC-Rio, 2002 


\section{Anexo 1: Roteiro para as entrevistas}

1 - A empresa estimula que os colaboradores tenham liberdade/autonomia para realizar sugestões e para tomar decisões? Há recompensas ou reconhecimento para os colaboradores que apresentam essas sugestões ou tomam decisões?

2 - Você acredita que, de maneira geral, a Reserva é uma empresa voltada para a inovação? A empresa se antecipa às tendências e busca inovações tecnológicas para seus produtos e processos?

3 - A empresa incentiva que seus colaboradores tomem riscos ou cria resistências? Os líderes apoiam os colaboradores assumindo os riscos? A empresa apoia o líder e/ou o colaborador que falha?

4 - Você acredita que a Reserva seja uma empresa proativa em relação ao mercado que está inserida, aproveitando oportunidades, inserindo novos produtos e serviços antes dos seus concorrentes? A mudança é algo constante e natural para a empresa?

5 - Há preocupação em realizar pesquisas com o consumidor final para avaliar a qualidade dos seus produtos e serviços? E a Reserva monitora os concorrentes e seus respectivos produtos e serviços e responde rapidamente aos movimentos/ataques realizados por estes? A empresa investe em marketing para se diferenciar?

6 - Como você vê a relação da empresa com os seus clientes e parceiros? $O$ que a empresa faz para fortalecer seu relacionamento de longo prazo com os clientes e parceiros? É comum realizar parcerias para desenvolvimento de novos mercados ou novos produtos?

7- A empresa monitora seus clientes de forma a compreender suas dores e necessidades e buscar soluções pioneiras para atender os mercados? As informações dos clientes são usadas para desenvolvimento de novos produtos e serviços?

8 - De que forma você acredita que o ambiente de trabalho físico da empresa (seja na sede, seja nas lojas ou no cd) influencia o seu trabalho? Como você descreve o clima/ambiente da empresa?

9 - Você conhece as ações do departamento de felicidade, como elas afetam o seu dia a dia?

10 - Como as lideranças da companhia influenciam a empresa? Você acredita que as lideranças incentivam o empreendedorismo na companhia?

11 - Qual o propósito da Reserva e como ele se conecta com os seus propósitos? Você acredita que, de maneira geral, os funcionários da empresa são engajados no propósito da empresa? 